
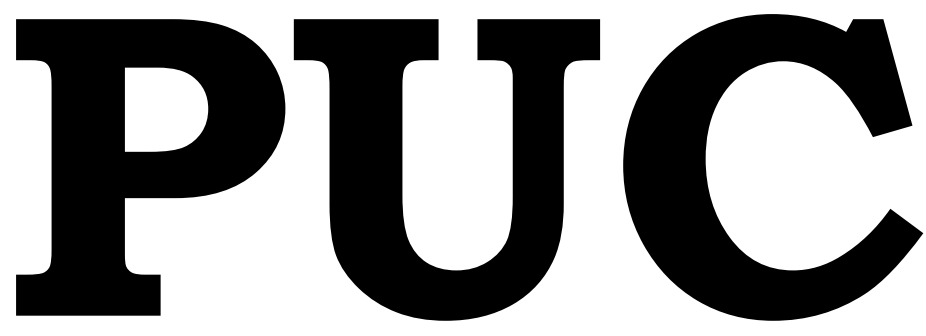

DEPARTAMENTO DE DIREITO

Contratos de Trabalho: conflitos de lei e de jurisdição no que tange aos trabalhadores maritimos brasileiros de navios cruzeiro.

por

Diego Freitas Leite Pinto.

ORIENTADOR(A): Daniela Trejo Vargas.

2013.2

PONTIFÍCIA UNIVERSIDADE CATÓLICA DO RIO DE JANEIRO

RUA MARQUÊS DE SÃO VICENTE, 225 - CEP 22453-'

$$
\text { RIO DE JANEIRO - BRASIL }
$$




\section{Contratos de Trabalho: conflitos de lei e de jurisdição no que tange aos trabalhadores maritimos brasileiros de navios cruzeiro.}

por

Diego Freitas Leite Pinto.

Monografia apresentada ao Departamento de Direito da Pontificia Universidade Católica do Rio de Janeiro (PUC-Rio) para a obtenção do Título de Bacharel em Direito.

Orientador(a): Daniela Trejos Vargas. 


\section{Dedicatória}

À minha família, amparo de que sempre precisei nos árduos momentos da vida. À minha namorada, Amanda Moraes, amor que ilustra a compreensão no encarar da vida. E a meu avô, Paulo Afonso de Freitas, exemplo do alarido demonstrado pela vida quando de sua majestosa trajetória trilhada.

Em memória de meu avó, Eduardo Leite Pinto, homem de bem, insígnia enraizada, de quem tenho muito orgulho de ser uma parte da história de vida que não acabou em 1.982 . 


\section{Agradecimentos}

Agradeço, unic amente e em especial, à Procuradora do Trabalho Dra. Júnia Bonfante Raymundo, pessoa que me proporcionou o contato com a temática e que sempre me incentivou nos estudos justrabalhistas que tanto enriquecem a mente daqueles que adentram nesta militância. É e continuará sendo um exemplo a ser seguido por tantos quantos tiverem a oportuni dade de compartilhar experiências sócio jurídicas com a sua pessoa. Muito obrigado pelo carinho, atenção, e ensinamentos. 


\section{RESUMO}

Esta monografia tem por objetivo demonstrar as idiossincrasias existentes quando da análise jurídica de uma categoria peculiar de trabalhadores: os marítimos que laboram em navios cruzeiro. Nessa esteira, são identificadas as influências de fenômenos híbridos multifacetados, de Tratados Internacionais multilaterais ratificados ou não, a existência do conflito de leis no espaço e de jurisdição que acomete os representantes da referida classe, e de um órgão ministerial de defesa dos direitos sociais, coletivos e transindividuais. Conclui-se pela aplicação da legislação mais benéfica ao obreiro, e pelo reconhecimento da competência da Justiça do Trabalho brasileira, haja vista a onipresença das clásulas constitucionais, dos princípios setoriais trabalhistas e do postulado do acesso à justiça.

Palavras Chave: marítimos; conflito de leis; conflito de jurisdição. 


\begin{abstract}
The text tries to demonstrate the idiosyncrasies that exist when analyzing a particular category of workers: seafarers who work on cruise ships. On this track, the paper identifies the influences of hybrid multifaceted phenomena, the multilateral international treaties ratified or not by Brazil, the existence of the conflict of laws in and jurisdiction issues, that affect the representatives of that working class, and a ministerial body defense of social and collective rigth. It concludes by applying the law most beneficial to the workers, and the recognition of the jurisdiction of the Brazilian Labor Courts, given the ubiquity of constitutional clauses, the sectoral principles and the postulate of free justice access.
\end{abstract}

Key words: seafarers; conflict of laws; international jurisdiction. 


\section{SUMÁRIO}

\section{INTRODUÇÃO.}

$1^{\circ}$ CAPÍTULO - Uma visão apriorística do Trabalho.

1.1. Globalização e seus efeitos sobre o trabalho.

1.2. O fenômeno da Internacionalização do trabalho no Brasil.

1.3. Um exemplo de internacionalização do trabalho: Trabalhadores marítimos brasileiros e navios cruzeiro.

1.4. A proteção do trabalho no plano internacional: Convenções da OIT. As Convenções sobre trabalho marítimo. Influência/Diretriz de Convenções da OIT ratificadas e não ratificadas e sua utilização como doutrina.

$2^{\circ}$ CAPÍTULO - Contrato internacional de trabalho: lei aplicável e jurisdição.

2.1. Conflito de leis no espaço.

2.2. Utilização do método conflitual (regra de cone xão tradicional).

2.3. O princípio da autonomia da vontade e a cláusula de lei aplicável.

2.4. O princípio protetor do Direito do Trabalho.

2.5. O cancelamento da Súmula 207 do TST e a lei 7.064/82.

2.6. Conflito de jurisdição. Competência Concorrente da Justiça do Trabalho.

2.7. O princípio da autonomia da vontade e a cláusula de eleição de foro.

$3^{\circ}$ CAPÍTULO - Trabalhadores em navios de cruzeiro.

3.1. Trabal hadores marítimos brasileiros e navios cruzeiro.

3.2. Prestação laborati va em águas territoriais brasileiras e estrangeiras: lei aplicável e jurisdição.

3.3. Atuação do MPT.

3.4. A concretização das cláusulas constitucionais - $\operatorname{artigo~} 6^{\circ}$ e $7^{\circ}$, XXII e XXXI da CRFB.

3.5. Acesso à justiça dos trabal hadores brasileiros em navios cruzeiro.

CONCLUSÃO.

BIBLIOGRAFIA. 


\section{LISTA DE ABREVIAÇÕES}

- CRFB/88- Constituição da República Federativa do Brasil de 1.988.

- CLT - Consolidação das Leis do Trabalho.

- CPC - Código de Processo Civil.

- CC - Código Civil.

- DIPr - Direito Internacional Privado.

- OIT - Organização Internacional do Trabalho.

- LIN - Lei de introdução às normas do Direito Brasileiro.

- LICC - Lei de Introdução ao Código Civil.

- REB - Lei de Registro Especial Brasileiro.

- LESTA - Lei de segurança na navegação nas águas de jurisdição nacional.

- NORMAN - Norma da autoridade marítima.

- MPT - Ministério Público do Trabalho.

- TAC - Termo de Ajustamento de Conduta.

- TST - Tribunal Superior do Trabalho.

- UNCITRAL - Comissão das Nações Unidas para Direito Comercial Internacional.

- LTDA - Sociedade Limitada.

- DPC - Diretoria de Portos e Costas da Marinha do Brasil.

- PNT - Profissional não tripulante.

- TNA - Trabalhador não aquaviário.

- CNIG - Conselho Nacional de Imigração.

- UNIDADES “OFF-SHORE” - Plataforma/Embarcação que se fixa nos oceanos e possui capacidade de locomoção. 


\section{INTRODUÇÃO}

Este trabalho trata de temática não muito popular, mas que revela-se de singular importância para a seara justrabalhista, dada a idéia imperativa da universalização dos direitos trabalhistas. Trata-se do conflito de leis e de jurisdição que acomete os trabalhadores marítimos brasileiros de navios cruzeiro. Dividiu-se o trabalho em três momentos. O primeiro reflete uma visão do trabalho como fenômeno social, e sua relação com outros fenômenos híbridos como a globalização, a internacionalização do trabalho e a precarização do mesmo, além da importância

ressaltada às Convenções da OIT no que tange às funções interpretativo-diretivas; o segundo versa sobre o conflito de leis e de jurisdição no que diz respeito àqueles; e o terceiro, de cunho lógico sistemático, versa sobre a solução a que se che gou e sobre a atuação do órgão ministerial constitucionalmente competente.

Observa-se, primeiramente, que se realça o fato de o processo globalizante estar inteiramente relacionado com o trabalho e suas diferentes formas de manifestação, além de ser causa para o surgimento de outros fenômenos sócio-jurídicos como a precarização do trabalho e a internacionalização do mesmo, que acabam por se inter-relacionar. A tendência globalizante atua de forma a influenciar a Economia, o Direito, a Política, a Sociedade, e o "mundo do trabalho", consequentemente, e é deste atuar que se percebe a desvalorização da mão de obra e a ampliação das desigualdades sociais que pairam pelos ares justrabalhistas. Percebe-se, pois, que a transformação no modus operandi trabalhista, advindo da nova era anunciada pela globalização e seus efeitos conexos, foi e é capaz de flexibilizar e enfraquecer as relações de trabalho lato sensu, de modo a deixar trabalhadores como os marítimos, desamparados, em um "limbo jurídico". Não se está aqui apenas a metaforizar. $\mathrm{O}$ intento é o de expor a realidade. 
Junto a este cenário jurídico-social surgem as Convenções da OIT, que desde 1.919 tem trazido os mais diversos benefícios às classes de trabalhadores como um todo. Deve-se entender o escopo dos Tratados multilaterais supracitados sob dois ângulos que dependem do fato de estarem ou não ratificados, ou seja, integrados ou não ao corpo normativo pátrio. Caso não haja a ratificação, independentemente do compromisso internacional a que se tenha obrigado, servem as Convenções como influência/diretriz interpretativa e teleológica, o que significa dizer que devem ser tidas como doutrina. ${ }^{1}$ Ao revés, aquelas que passarem pelo processo de incorporação, assumem status de lei ordinária federal, de ve ndo, portanto, ser fielmente seguidas. . Desde a EC 45 de 2004, os tratados que versam sobre direitos humanos, podem ter o mesmo status de emenda constitucional, se ratificados com o quórum qualificado pre visto no parágrafo $3^{\circ}$ do artigo $5^{\circ}$ da Constituição Federal.

Em uma segunda parte, evidencia-se o cerne da questão suscitada neste trabalho monográfico, qual seja o conflito de leis no espaço e o simultâneo conflito de jurisdição. Os marítimos que pactuam junto às empresas de navios cruzeiro, se encontram em uma situação um tanto quanto desconfortável, visto que ora se afirma a prevalência da legislação internacional, ora não, subsistindo a doméstica. Assim, importa saber se o método conflitual do Direito Internacional Privado terá vez, ou se se optará por uma interpretação mais benéfica a este seleto grupo de operários. Opta-se no dissertar do texto pelo princípio da interpretação mais benéfica ao trabalhador, pelo viés do Princípio Protetor do Direito do Trabalho e da L. 7.064/82, artigo $3^{\circ}$, II, de modo que a este seja assegurada a aplicação da lei que lhe traga maior resguardo, independentemente de esta proposta hermenêutica estar ou não de acordo com o artigo $9^{\circ}$ da LIN, que representa a regra de cone xão tradicional. Ou seja: tanto a legislação doméstica, quanto a estrangeira são aplicáveis, desde que tragam maior segurança e be nefícios jurídico-sociais.

\footnotetext{
1 Henry Batiffol e Geraldo Eu lálio do Nascimento e Silva destacam a importância dos tratados não-ratificados, e sua qualificação co mo fonte subsidiária de dire ito internacional. Dolinger, Jacob, Dire ito Internacional Privado (Parte Geral), $7^{\mathrm{a}}$ ed. Editora Renovar, 2003, pp.73-74.
} 
Afigura-se como de crucial relevância o ponto referente ao conflito de jurisdição e o reconhecimento da competência concorrente internacional da Justiça laboral especializada brasileira. Não se poderia chegar a outra conclusão, senão a de que é competente concorrentemente, vide artigo 88, I, II, III do CPC c/c artigo 114, I, da CRFB/88, a Justiça do Trabalho, para conhecer, processar e julgar as causas que envolvam trabalhadores marítimos brasileiros que prestam seus serviços em navios cruzeiro. O conflito de jurisdição no que diz respeito ao tema abordado enc ampa-se na teoria, pois na prática é de fácil solução, eis que a normatização constitucional e processual civil possuem permissivos legais que possibilitam a conclusão pela competência da Justiça provedora dos Direitos Sociais trabalhistas.

Cabe ressaltar, neste momento, que o princípio da autonomia da vontade e as cláusulas de lei aplicável e de eleição de foro, não foram analisados profundamente, visto que a inclusão destes no contrato internacional de trabalho não af asta o projeto hermenêutico que ora se constrói, podendo, com tranquilidade, serem obstadas para serem aplicadas, tanto a legislação pátria quanto a internacional, assim como ser tida como competente a Justiça justrabalhista.

Por fim, chega-se a finalidade objetivada desde o princípio: reconhecer a aplicação da lei mais benéfica ao marítimo brasileiro, e a possibilidade do exercício da jurisdição estatal pela Justiça do Trabal ho. Cumulado a este pensamento, realça-se o importante papel do Ministério Público do Trabalho na defesa dos direitos transindi viduais ostentados por seus respectivos titulares, de maneira que, a atuação precípua constitucional deste órgão ministerial mostra-se meio adequado e eficaz na concretização e progressão daqueles, sendo pois, capaz de perfectibilizar as cláusulas constitucionais referentes aos direitos sociais como um todo, e em especial, $\mathrm{o}$ artigo $6^{\circ}$ e o artigo $7^{\circ}$, XXII e XXXI. 
Eis uma pequena demonstração do que será tratado em todo o texto.

\section{1ำ Capítulo - Uma visão apriorística do Trabalho}

\subsection{Globalização e seus efeitos sobre o Trabalho.}

O "mundo do trabalho" ao longo dos séculos, tem sido afetado pelos mais variados tipos de e voluções e processos, naturais e artificiais, os científicos, políticos, econômicos, jurídicos, e sociais, que determinam. Há em especial um processo, que tem crescentemente influenciado as relações de trabalho: a chamada mundialização, ou, como é mais chamada, globalização.

A globalização, fenômeno intrinsecamente ligado ao capitalismo, demonstra a integração econômica, cultural, social e política entre os diversos países e suas respectivas sociedades. Sabe-se que esta proporcionou a "expansão dos mercados" e no que tange ao mercado de trabalho, verificou-se mudanças substanciais, que são de certa forma, inquietantes. $\mathrm{O}$ efeito globalizante definitivamente consolidado com o avanço tecnológico diminuiu a importância da matéria-prima e da mão-de-obra direta, ampliando as desigualdades sociais e trazendo como resultados o desemprego, a pobreza e a escravidão. Isto porque o Estado passou a ser pressionado para agir como garantidor dos interesses econômicos a fim de superar a desigualdade produtiva, mesmo que isso significasse recuar nas conquistas sociais alcançadas pelas sociedades ao longo de muitas décadas. ${ }^{2}$

Este fenômeno multifacetado expressa a era da modernidade que se consubstancia em três expoentes: a tecnologia, a informação, e o consumismo. A evolução científica nos permite um contato próximo, diário, corriqueiro, com as ino vações, facilitando, ou em muitos casos até dificultando, a vivência. Não obstante, obtém-se cada vez mais informação sobre qualquer ass unto, qualquer tendência, sobre

2 MATTOS, Vivian Rodrigues. O trabalho na era da globalização. Disponível em <http:// jus.com.br/revista/texto/4845/o-trabalho-na-era-da-globalizacao>. Acesso em 23 de março de 2013. 
tudo. É possível, pois, perceber que o planeta no qual se vive está cada vez mais integrado, o que não significa dizer que isto seja tão benéfico como se quer que seja, a exemplo do lado obscuro do consumismo que "corrói" os seres humanos como um todo.

Cabe notar que o crescimento, a transformação e a flexibilização no "modus operandi" da vida nem sempre é sinônimo de alegria. Evidencia-se juntamente com este desenrolar a mudança na regulamentação social e, consequentemente, a flexibilização do mercado de trabal ho. O trabalhador nesta conjuntura é tido como um objeto à disposição da internacionalização do mercado de trabalho que é fruto desta árvore denominada globalização. Desta forma, consegue-se ver que a dimensão econômica que embasa este procedimento de caráter internacional acaba por contribuir para a des valorização e a degradação do labor.

Torna-se igualmente importante frisar que a de gradação do trabalho ou como os juristas e demais estudiosos costumam dizer, "precarização do trabalho", é consequência direta do processo de globalização que acomete os mais diversos trabalhadores das mais diversas categorias. Criou-se uma severa competição entre países social e economicamente desiguais, o que deu margem a uma espécie de concorrência desleal, com diminuição da proteção social e a precarização supracitada, marcada pela utilização de mão de obra estrangeira em condições de trabalho desumanas, e com remuneração incapaz de suprir as necessidades vitais básicas do trabalhador. ${ }^{3}$ Desde logo, observa-se que a transnacionalização dos mercados deu ensejo a uma flexibilização das normas trabal histas como um todo o que dificultou o amparo jurídico-social do trabalhador.

É de se concluir que o trabalhador é parte cada vez mais vulnerável na relação de trabalho e no mercado respectivo, e a ilustração disto, é o fato de as empresas alterarem os níveis salariais, ajustarem os níveis da atividade laboral (quantidade, duração, natureza das tarefas, por exemplo), e modificarem os contratos de trabalho

3 GODOY, Dagoberto Lima. Globalização e Trabalho: por quê $e$ o que flexibilizar. <http://www.white.oit.org.pe/dial2002/documentos/globalizacao_trabalho_flexibilizar.pdf >. Acesso em 23 de março de 2013. 
no que tange a jornada de trabalho, intervalo intra-jornada, remuneração, e outros aspectos, em função dos interesses societários. ${ }^{4}$ Portanto, vê-se que a flexibilização é caus a para a as alterações legislativas, negociações coletivas, alterações nos contratos de trabalho, e decisões dos empre gadores, ao mesmo tempo em que é consequência do complexo processo globalizante.

${ }^{4}$ Ibid. 


\subsection{O fenômeno da Internacionalização no Brasil}

A dinamicidade da relação laboral deu ensejo à mudança de paradigma no que diz respeito ao lugar da prestação de serviços. Até pouco tempo atrás trabalhava-se ape nas na cidade onde se residia, o que hoje não mais se perfaz. É notório que as fronteiras e as dificuldades ainda existem, mas presencia-se a redução das barreiras ao trabalhador que são conjugadas ao aumento das oportunidades de trabalho e da concorrência às vagas disponíveis no mercado. ${ }^{5}$ Se está a dizer que é praxe ver trabalhadores, não só brasileiros, mas também de outras nacionalidades, prestarem seus esforços fora dos limites territoriais dos Estados dos quais são nacionais.

Assim, avista-se uma tendência que há muito se infiltrou no mercado de trabalho, qual seja a da prestação laborativa fora do país de origem. No Brasil, a internacionalização do trabalho se deu muito influenciada pela globalização e seus efeitos (já abordados em tópico anterior) o que demonstra nos dias atuais uma prática comum, corriqueira. Quando do início de tal ato, pensava-se na melhoria das condições de trabalho e da contraprestação laborativa, o que posteriormente, comprovou-se não ser o que se almejava. O american way of life encheu os olhos de muitos brasileiros que saíram em busca de uma vida melhor e mais digna. Entretanto, a realidade fática restou soberana e fez mostrar àqueles que a discriminação sócio-racial embasada em um preconceito "natural" existente nos países desenvolvidos para com os latinos americanos em desenvolvimento, prescreve aquilo que já era pre visto por muitos: a não valorização do trabalhador brasileiro, reservando-se para este, salvo raras exceções, o terceiro setor caracterizado pela marginalização do mercado de trabalho.

Desta maneira, verifica-se que os processos de globalização e de internacionalização do trabalho conduzem o trabalhador brasileiro, que não possui

\footnotetext{
5 FASSARELA, Lúcio. Globalização do Trabalho. <http://blog.ufes.br/luciofassarella/2013/04/05/internacionalizacao-do-trabalho>. Acesso em 02 de abril de 2013.
} 
qualificação capaz de alçá-lo a um nível melhor no mercado, para uma única direção, qual seja a da des valorização, e neste sentido o brasileiro é cada vez mais vítima dos excessos patronais, como os freqüentes assédios morais e sexuais.

Diante desta conjuntura deturpada, conclui-se que o efeito globalizante e a internacionalização do trabalho são fenômenos que, via de regra, propiciam a precarização do meio ambiente de trabalho, a qual acaba por abarcar, infelizmente, os brasileiros que adentram nesta aventura em busca de sonhos utópicos que não se concretizam.

Exemplo claro da precarização é o dos trabalhadores brasileiros de navios cruzeiro, os quais ingressaram neste ramo laboral muito por influência do fenômeno da internacionalização, e que se encontram hoje em um verdadeiro "limbo jurídico", que não lhes proporciona a devida proteção legal. De ve-se ter em mente que todo e qualquer trabalhador tem o direito a ter a sua dignidade constitucional preservada, vide artigo $1^{\circ}$, III, da CRFB, que também é sinônimo do "direito de possuir direitos".

Portanto, o que se quer é fundir a teoria com a prática. A regularidade das práticas patronais e a globalização acompanham a internacionalização do trabalho, proporcionando a desvalorização da mão de obra exportada. Os estudos doutrinários que desembocam em Convenções da OIT são os meios de maior prudência e efetividade que se tem em mãos para suprimir esta situação vexatória de cunho degradante e, promover o reconhecimento da igualdade no trabal ho em nível global. 


\subsection{Um exemplo de Internacionalização do Trabalho: trabalhadores marítimos e navios cruzeiro.}

Os trabalhadores marítimos brasileiros que trabal ham em navios cruzeiro, como dito anteriormente, refletem um exemplo de internacionalização do trabalho, pois que muito influenciados pelo processo de globalização, que por sua vez, reflete as tendências mercadológicas. Muitos cidadãos brasileiros se veem tentados a ingressar neste ramo de trabalho referente aos "navios de lazer", "de passageiros", muito em função da idéia de que o trabalho em alto-mar aliado a uma remuneração um pouco maior e a um labor "aconchegante", dado o exercício de um ofício em "navio de luxo", com passageiros que possuem boa condição econômico-financeira, proporcionaria melhores condições de trabalho e até uma projeção internacional. Trat a-se de um cenário atrati vo e ilusório capaz de angariar muitos brasileiros, que de boa-fé, aceitam a oportunidade na esperança de melhorar a vida própria.

Todavia, não é este o quadro que se faz presente na realidade. O Ministério Público do Trabalho, instituição pertencente ao Ministério Público da União, conforme o artigo 128 da CRFB, responsável pela defesa dos interesses difusos e coletivos, à vista da instauração da ordem democrática, de todos os trabalhadores brasileiros, recebe denúncias corriqueiras sobre o descaso para com os empregados brasileiros que se aventuram nestes cruzeiros, os quais ilustram a inversão do pensamento obtido por aqueles que optam por oferecer sua mão de obra àqueles. Verifica-se na prática junto às representações, procedimentos preparatórios de inquérito, inquéritos civis públicos, e ações civis públicas, a ocorrência de maus-tratos, péssimas condições de trabalho, assédio moral e sexual, dentre outros óbices que concretizam o fenômeno da precarização do trabalho.

Esta é a realidade que torna-se cada vez mais contínua e habitual. Antes de vir a ser uma "questão jurídica" é uma "questão social" que demonstra a ausência de regras de trato social junto a esta categoria profissional, a qual elimina destas relações de 
emprego, o respeito às pessoas que ali estão prestando seus ofícios à empresas que buscam contornar as leis e tratados internacionais para realizar seus objetivos e interesses econômicos, explorando o potencial turístico da costa brasileira.

Há outras incongruências que devem ser citadas além da realidade laboral, quais sejam: a escassez normativa, a indeterminação conceitual e a ausência de proteção legal efetiva aos que se iniciam nas jornadas marítimas. Quando se fala em escassez normativa, quer se referir à falta de diplomas legais consolidados, de fácil entendimento e de grande publicidade. Cabe aqui a feitura de uma pequena digressão. Getúlio Vargas, quando em seu go verno anunciou, mediante o Decreto-Lei 5.452/43, a Consolidação das Leis Trabalhistas, em sua exposição de motivos, ressaltou a importância de se ter uma lei trabalhista de fácil linguajar que seja acessível a todos, pois que o Direito Social, regerá relações jurídicas que garantem a subsistência de todo e qualquer brasileiro. Deve-se ter legislações laborais acessíveis a todo trabalhador, porque dessa forma, resguarda-se, seguramente, os direitos que advém daquela relação jurídica.

A escassa base normativa do trabalho marítimo é composta de quatro diplomas legais, quais sejam, a Portaria n ${ }^{\circ}$ 104/07 da Diretoria de Portos e Costas da Marinha do Brasil, a Resolução Normativa $n^{\circ} 72 / 06$ do Conselho Nacional de Imigração, a L. 9.432/07 que define o Registro Especial Brasileiro para embarcações, e a LESTA - L. 9.537/97, que dispõe sobre a segurança do tráfego aquaviário em águas sob a jurisdição nacional. A análise destes permitirá observância não só da primeira incongruência, como das outras duas referidas acima.

O que se mostra relevante nestes diplomas é a definição de tripulante, que deve ser entendida como sinônimo de trabalhador marítimo. O dicionário de vocabulário jurídico De Plácido e Silva define tripulante como sendo:

"De tripular, a rigor técnico, é o vocábulo empregado para designar o marinheiro ou a pessoa que loca seus serviços para misteres em uma embarcação. $O$ tripulante, pois, é integrante da gente da tripulação, como marinheiro ou serviçal. Os tripulantes são contratados pelo capitão, estando sujeitos à matrícula nas Capitanias do Porto, que lhes fornecem as cadernetas necessárias a esse ajuste ou engajamento." 
É esta a verdadeira etimologia da palavra tripulante que possui previsão no Código Comercial pátrio, artigo 564, o qual determina a inclusão no conceito de equipagem, considerada para fins normativos como sendo tripulação, todos aqueles que no navio laboram. Encampa-se assim, tanto os oficiais do navio, como as pessoas que nele prestam serviços.

A Portaria n ${ }^{\circ} 104$ de 2007 expedida pela Diretoria de Portos e Costas da Marinha do Brasil aprovou a NORMAM - 24/DPC, norma da autoridade marítima, que versa sobre o credenciamento de instituições para ministrar cursos para profissionais não tripulantes e tripulantes não aquaviários. Os cursos dizem respeito à sal vaguarda da vida humana no mar e à segurança e proteção de navios e instalações marítimas, o que por ora não será objeto de análise. Cumpre esclarecer, que o propósito é a verificação das definições dadas pelos referidos atos normativos, e esta norma definiu o profissional não tripulante (PNT) como sendo "todo aquele que, sem exercer atribuições diretamente ligadas a operação da embarcação, presta serviços e ventuais a bordo."

Também afirmou que o tripulante não aquaviário (TNA): "é aquele que faz parte da tripulação marítima das unidades "offshore" móveis e das plataformas, exercendo funções referentes à operação dessa unidades, as quais estão definidas em normas da AMB.”

Observa-se que os dois conceitos acima expostos são bem restritivos e específicos, o que não permite o enquadramento dos trabalhadores marítimos de cruzeiro como profissionais tripulantes lato sensu, ou seja, como marítimos, não sendo também possível a representação sindical. Trata-se do "limbo jurídico", pois não se enquadram nas definições dadas pelos instrumentos normativos. O mesmo se dará nas normas posteriores.

A L. 9.432/97, conhecida como REB, dispõe sobre a ordenação do transporte aquaviário, estipulando como necessário para a circulação em águas jurisdicionais brasileiras o Registro Especial Brasileiro, que não exclui outros que se fizerem necessários. Esta lei em seu artigo 11, $\S 12^{\circ}$, faz uma ressalva, atribuindo ao Poder 
Executivo da União "a atribuição de regulamentar o REB, estabelecendo as normas complementares necessárias ao seu funcionamento e as condições para a inscrição de embarcações e seu cancelamento." E assim o Executivo o fez, emitindo o Decreto 2.256/97, que não só regulamentou o referido registro, como também definiu tripulante em seu artigo $3^{\circ}$, VII, dizendo ser "o trabalhador aquaviário, com vínculo empregatício, que exerça funções, embarcado na operação da embarcação". Há, no entanto, uma crítica a ser feita neste momento às definiçõoes obtidas dos dois diplomas legais citados anteriormente, que é o fato de não se incluir no conceito de tripulante aquelas pessoas que não trabalham operando a embarcação. Aqueles que laboram em navios de passageiros encontram-se, novamente, neste espaço es vaziado de proteção legal. Não se vislumbra assim, a proteção efetiva desses trabalhadores, pois que a indeterminação conceitual se faz presente.

O mesmo Decreto também deixou a desejar, quando em seu artigo $8^{\circ}$, mencionou que as convenções e acordos coletivos de trabalho regerão as condições de trabalho para as tripulações das embarc ações registradas no REB, estipulando, dentre outras normas, as relativas à remuneração e ao regime de férias. Não há mal algum na ressalva feita no artigo, desde que se tenha o enquadramento sindical que permita o sindicato, a federação ou a confederação representati vos da categoria profissional em voga, celebrar os ne gócios coletivos trabal histas. Ocorre que a conceituação exposta nas leis e atos normati vos citados não permite o adequado enquadramento, segundo os ditames do artigo 577 da CLT. Este é o impasse.

Por fim, a LESTA - L. 9.537/97, também estabelece definições não abrangentes, específicas, que retiram os trabalhadores marítimos de navios cruzeiro das nomenclaturas de "tripulante" e "aquaviário", o que reforça a ausência de amparo jurídico efetivo. $\mathrm{O}$ artigo $2^{\circ}$, II, desta lei, define aquaviário como sendo "todo aquele com habilitação certificada pela autoridade marítima para operar embarcações em caráter profissional". Também conceitua tripulante, no inciso XX do mesmo artigo, como sendo o "aquaviário ou armador que exerce funções, embarcado, na operação da embarcação". Chega ao ponto de até qualificar profissional não tripulante, assim 
como o foi na Portaria $n^{\circ}$ 104/07 da DPC, como sendo "aquele que, sem exercer atribuições diretamente ligadas à operação da embarcação, presta serviços e vent uais a bordo", o que não enseja a adequação dos marítimos aqui tratados nesta conceituação (e não poderia o ser, pois que os mesmos não são prestadores de serviços eventuais, porque possuem contratos de trabal ho que estabelecem prestações habituais, mas a atenção chamada é relevante para mostrar que neste tópico estes não estão abrangidos).

A lei supracitada é regulamentada pelo Decreto 2.596 de 1998, que em seu artigo $1^{\circ}$, I, define trabalhador marítimo: "tripulantes que operam em embarcações classificadas para navegação em mar aberto, apoio portuário e para a nave gação interior nos canais, lagoas, baías, angras, enseadas e áreas marítimas consideradas abrigadas". Verifica-se assim, o efeito não globalizante da definição que permite assim como as outras ditas acima, a propagação da indeterminação conceitual, da proteção efetiva e da escassez normativa, de modo a tornar o trabal hador marítimo em voga al vo dos abusos patronais e do descaso legal.

Por fim, insta ressaltar que a Resolução Normativa do Conselho Nacional de Imi graç ão (CNIG) n ${ }^{\circ} 72$ de 2006, disciplinou a chamada de profissionais estrangeiros, sem vínculo empregatício no Brasil, para trabalho a bordo de embarcação ou de plataforma estrangeira em águas jurisdicionais brasileiras. O escopo desta resolução, assim como exposto na REB, artigo $4^{\circ}$, é permitir a admissão de marítimos e outros profissionais brasileiros, segundo a proporcionalidade insculpida no artigo $3^{\circ}$ desta, em navios estrangeiros, de bandeiras estrangeiras, que naveguem em águas territoriais brasileiras. Quer-se privilegiar o trabalhador marítimo brasileiro, ou melhor, o seu acesso a estas embarcações, aos postos de trabalho nestas, o que parece ser, em princípio, justo, face às indefinições legais antes expostas. Trata-se do mínimo necessário.

Dado o exposto, percebe-se que o de vido resguardo legal a estes trabalhadores nunca se fez presente. Contudo em 2010 houve a celebração do Termo de Ajuste de Conduta $\mathrm{n}^{\mathrm{o}}$ 408, firmado pelo Ministério Público do Trabalho, na Procuradoria 
Regional do Trabalho da $1^{\mathrm{a}}$ Região, de abrangência nacional, junto à empresa MSC Cruzeiros do Brasil Ltda (exploradora da atividade econômica referente ao trans porte de passageiros em território nacional e internacional), que se obrigou, a manter quando navegar em águas jurisdicionais brasileiras um número mínimo de $25 \%$ de brasileiros nas embarcações turísticas; a contratar formalmente os brasileiros recrutados para laborar embarcados durante a temporada de cruzeiros pela costa brasileira (ou na ausência desta pelo agente marítimo responsável pela operação da embarcação), devendo ser o contrato de trabalho escrito, no idioma português e vinculado à legislação trabalhista aplicável à espécie, conforme o artigo $8^{\circ}$ da $\mathrm{RN}$ 71/06; a remunerar os nacionais nos mesmos valores dos demais tripulantes que exerçam funções idênticas, devendo ser indicadas, no caso da existência de gorjetas, sua forma isonômica de distribuição; a garantir jornada de trabalho, inclusive os intervalos intrajornada e interjornada, dos brasileiros a bordo da embarcação, consoante o previsto nas Convenções Internacionais da OIT ratificadas pelo Brasil, salvo acordo ou convenção coletiva estipulados por organização sindical que represente os mesmos; a manter equipe médica, médico ou enfermeiro, a bordo, que seja brasileiro com vistas a facilitar o atendimento de tripulantes brasileiros; a respeitar regras estabelecidas nos códigos de ética relativos às condutas explicitadas como assédio moral e sexual, com vistas a preveni-las e evitá-las nas relações dos superiores com a tripulação; dentre outras medidas.

Assim, percebe-se que o esforço resultante da formação do referido TAC, foi e é, o instrumento normativo que vigora e ampara aqueles que adentram na jornada marítima em navios cruzeiro como os oferecidos pela empresa MSC Cruzeiros. A nítida escassez normativa ainda perpetua no ordename nto jurídico pátrio, não sendo o Termo citado capaz, por si só, de promover a igualdade de tratamento e de direitos dos marítimos, sejam estes brasileiros ou não. Para sanar essa lacuna normativa, espera-se a ratificação da Convenção do Trabalho Marítimo de 2006 da OIT, e a aprovação do projeto de lei n n $^{\text {4 }}$ direitos desta classe, para que se juntem ao conjunto de leis brasileiras trabalhistas e 
assegurem interesses e condições dignas de trabalho a este seleto grupo de "hipossuficientes". 


\subsection{A proteção do Trabalho no plano internacional - Convenções da OIT. Convenções sobre Trabalho marítimo. Influência/diretriz de Convenções da OIT ratificadas e não ratificadas e sua utilização como doutrina.}

Os operadores do Direito comungam a idéia de que a origem do Direito se justifica, precipuamente, pela intenção de regular a vida em sociedade. O Direito, instrumento capaz de estabelecer, preservar e impor a ordem jurídica, tem a finalidade primeira de possibilitar a vida em sociedade, seja a que se pertence ou a internacional. No Brasil, a referida ordem, no que diz respeito à proteção ao trabalho,está insculpida na Constituição Federal de 1988 , artigos $6^{\circ}, 7^{\circ}, 8^{\circ}, 9^{\circ}, 10^{\circ}, 11^{\circ}, 170^{\circ}$, dentre outros, na CLT (Consolidação das Leis do Trabalho), e em legislações esparsas e normas jurídicas de caráter secundário segundo o ilustre constitucionalista José Afonso da Silva, como decretos, portarias, e resoluções.

Por outro lado, na seara internacional, a efetiva proteção ao trabalho se dá por meio dos usos e costumes internacionais, dos princípios gerais de direito, das relações diplomáticas e da criação de Convenções e Tratados por Organizações Internacionais e Estados Soberanos. É sobre estas espécies normativas de caráter internacional/multilateral, que se esboçará algumas informações reveladoras e esclarecedoras, as quais pertencem ao campo do Direito Internacional, seja ele Público ou Privado.

É importante notar que muitos estudiosos entendem a palavra "Convenção" como sinônimo da palavra "Tratado", mas cabe aqui uma ressalva, qual seja a de que o Direito Comparado vem reservando à primeira os tratados multilaterais abertos adotados em conferências realizadas no âmbito de organismos internacionais ou regionais de direito público. ${ }^{6}$ São em geral tidas como "Tratados-Leis" ou "Normativos", os quais contrastam com os Tratados "stricto sensu" ou "Tratados-Contratos". É de se observar assim, que as Convenções organizadas e

${ }^{6}$ SUSSEKIND, Arnaldo. Convenções da OIT. 2a ed. São Paulo: LTr, 1.998. p. 30. 
criadas pela Assembléia Geral da OIT são "Tratados-Leis", multilaterais e abertos, que buscam a constituição de finalidades a serem alc anç adas mediante a imposição de obrigações de igual valor para todos os membros que aderem à Convenção (ou filiados). É por meio destas que as relações de trabalho no plano internacional, estando o plano interno abrangido por este, tornam-se protegidas, tuteladas, o que demonstra o amparo e o esforço feito para que as relações jurídico-trabalhistas estejam normatizadas.

Como já anteriormente referido, os trabalhadores marítimos brasileiros que prestam labor em navios cruzeiro de bandeira estrangeira, se encontram em um verdadeiro "limbo jurídico. Quer-se mostrar o papel crucial que as Convenções da OIT têm no amparo jurídico da categoria supracitada, sendo o seu objetivo primordial a união das vontades comuns dos países aderentes que perseguem o mesmo fim.

Para fins de esclarecimento, a abordagem será feita com base nas Convenções da OIT, ratificadas e não ratificadas, pois que ambas servem como influência/diretriz no plano externo e interno de cada país que as efetiva ou não. Faz-se importante a especificação dos diversos tipos que não poderiam ser melhor classificadas senão por Arnaldo Sussekind ${ }^{7}$, que as denomina: 1-) auto-aplicáveis - quando as disposições destas não requerem regulamentação complementar posterior para serem aplicadas pelos Estados que as ratificam; 2-) de princípios - que são aquelas que dependem da adoção de lei ou outros atos normati vos para a sua aplicação, a não ser quando existir norma interna compatível; 3-) promocionais - que fixam uma principiologia explicitada por determinados objetivos e programas de consecução das finalidades abordadas.

Também podem as Convenções versar sobre diversos temas, dentre eles os direitos humanos do trabalhador, política de empre go e desenvolvimento dos recursos humanos, igualdade de direitos e migração, populações indígenas e tribais, relações coletivas de trabalho, contrato individual de trabalho e condições gerais de emprego, condições especiais de trabalho, segurança, higiene e meio ambiente do trabalho,

\footnotetext{
${ }^{7}$ Ibid. p. 31.
} 
seguridade social, e administração do trabalho. Os objetos de estudo e normatização são os mais diversos possíveis, pois que visa-se o maior resguardo dos direitos e interesses das mais diversas classes de trabalhadores. ${ }^{8}$

Dando um passo à frente, pode-se vislumbrar três outros importantes pontos que se referem diretamente aos países que ratificam esta espécie singular de Tratado: a vigência internacional, nacional e a eficácia jurídica interna. Para que a abordagem ade quada seja feita com a densidade necessária, mister se faz a caracterização de cada um deles. Entende-se por vigência internacional o momento em que uma Convenção entra em vigor na esfera internacional, globalizada, que se dá no momento em que a Convenção é criada e promul gada no plano externo. Já a vi gência interna, é entendi da como o momento em que o Tratado passa a ter efeitos no plano interno, que se dá via de regra, 12 (doze) meses após a ratificação da Conve nção. Por fim, a eficácia jurídica interna é tida como o fenômeno do Direito Internacional Público que é um "adendo" da vigência nacional, ou seja, as normas estabelecidas mediante ato normativo internacional podem ter efeitos internos antes da norma internacional entrar verdadeiramente em vigor no plano interno, se a divulgação de seu texto se der antes do prazo estipulado para a vigência. ${ }^{9}$

A exposição acima leva à seguinte pergunta: a partir de que momento passa-se a ter a vigência nacional e a eficácia jurídica interna? A re posta a este questionamento encontra-se no artigo $19, \S 5^{\circ}$, a), da Constituição da OIT, e no artigo 49, I, da CRFB/88 que diz ser uma obrigação formal do Estado-membro da OIT (ou dos filiados) a submissão da Convenção à autoridade nacional competente para aprovação.

No Brasil, a competência para a aprovação é do nosso Parlamento, do Congresso Nacional. Contudo, é importante ressaltar que a aprovação se difere da ratificação, donde se verifica que a primeira deriva de ato legislativo cuja espécie é o Decreto Legislativo, que não é capaz de incorporar as normas do Tratado ao ordenamento

\footnotetext{
8 Ibid. p. 32.

9 Ibid. p. 40.
} 
jurídico brasileiro, e a segunda de ato do governo. Portanto, uma vez aprovada a Convenção pelo Poder Legislativo, pass a-se a ratificação pelo Poder Executi vo a qual se dará por ato de go verno do Presidente da República. Uma vez ratificada a espécie normativa prossegue-se à promulgação da ratificação do instrumento normativo, 12 (doze) meses após esta, entrando em vigência no plano interno. Todavia, se o ato de go verno destinado à di vul gação daquela se der neste interregno, há a eficácia jurídica interna. $^{10}$

A ratificação das Convenções pode tornar findo ou não este processo de incorporação. Há duas teorias do Direito Internacional Público que incidem sobre a questão, e estas são o Monismo e o Dualismo jurídico. A primeira entende que a ratificação de Convenção que contém normas auto-aplicáveis incorpora-se imediatamente ao ordenamento jurídico, não sendo necessário o compromisso de legislar para complementar o ato normativo internacional, dada a relação de interdependência que existe entre às ordens jurídicas interna e externa. Em contrapartida, o Dualismo se apóia na independência entre os ordenamentos, surgindo assim, para os países que o adotam, a obrigação formal, sob pena de responsabilidade internacional do Estado, de elaborar leis ou regulamentos que complementem e admitam o diploma ratificado no plano interno. ${ }^{11}$

O Tratado ratificado complementa, altera ou re voga o direito interno, desde que se trate de norma auto-aplicável e já esteja em vigor na esfera internacional. A fundamentação legal encontra-se na própria Carta Magna, no artigo 105, III, a), que admite recurso especial contra decisão que contrariar norma constante de Tratado ou negar-lhe vigência. ${ }^{12}$ Cabe ressaltar, todavia, que o Direito Internacional do Trabalho, não admite Convenção que contrarie lei, sentença, costume ou acordo que garanta condições mais benéficas ao trabalhador. Trata-se da aplicação do Princípio Protetor do Direito do Trabalho que também pertence ao "primo internacional".

Por fim, caso haja conflito entre a Convenção da OIT ratificada e a Constituição

\footnotetext{
${ }^{10}$ Ibid. p. 35 .

11 Ibid. p. 36.

12 Ibid. p. 37.
} 
da República Federativa do Brasil, esta última prevalecerá, pois segundo Carlos Maximiliano, sendo a "Constituição a lei suprema do país, contra a sua letra ou espírito não prevalecem tratado ou quaisquer atos diplomáticos". 13

Em função do exposto, é de se concluir que no caso de ratificação de uma Convenção da OIT a influência/diretriz tem caráter normativo, sendo a mesma de observância obrigatória pelos Estados aderentes.

Cabe destacar algumas Convenções da OIT, ratificadas e incorporadas pelo ordenamento jurídico brasileiro, que versam sobre trabalhadores marítimos: as de $\mathrm{n}^{\mathbf{o}}$ 92 e 133, que regulam o Alojamento da Tripulação; a de $n^{\circ} 163$, que trata do Bem-Estar dos Trabalhadores Marítimos no Mar e no Porto; a de n 91, que garante o direito às férias remuneradas aos trabalhadores marítimos, $\left(\operatorname{artigo} 3^{\circ}\right)$ da mesma; a de $\mathrm{n}^{\mathrm{o}} 109$, que garante o direito à uma jornada de trabal ho mínima, (artigo 14); e a de $\mathrm{n}^{\mathbf{o}}$ 185, que obriga o Estado a expedir documentação de identidade de "gente do mar", $\left(\operatorname{artigo} 2^{\circ}\right.$ ) desta, o que garante a identificação em âmbito internacional e os direitos de marítimo.

Neste passo, salienta-se a abrangência de duas das convenções citadas: a 92 e a 163. No que concerne à Convenção 92 de ve-se observar os artigos. $4^{\circ}, 5^{\circ}$, c), e $6^{\circ} .0$ primeiro diz, ipsis litteris: “Antes da construção do navio, os seus planos, mostrando numa escala prescrita, a localização e as disposições ferais dos alojamentos da tripulação, serão submetidos para a aprovação à autoridade competente." A alínea c) do artigo $5^{\circ}$ versa: "A autoridade competente inspecionará todo o navio e cientificar-se-á de que os alojamentos das tripulações estão de acordo com as condições exigidas pelas leis e regulamentos, sempre que uma acusação tenha sido feita à autoridade competente(...)".

Esta demonstra a possibilidade de postulação perante a (s) autoridade incumbida (s) da fiscalização das condições e meio ambiente de trabalho. Por fim, o artigo $6^{\circ}$ expõe:

13 Ibid. p. 40. 
"A localização, meios de acesso, construção e disposição dos alojamentos da tripulação em relação às outras partes do navio serão de forma a garantir adequada segurança, proteção contra as intempéries e o mar, bem como isolamento contra o calor, frio, ruído excessivo, odores ou emanações provenientes de outras partes do navio."

Percebe-se, pois, sob o ponto de vista específico dos alojamentos nas embarcações que abrigam os trabalhadores marítimos, que a proteção quanta a estes resta bem explicitada e efetivada.

Em outra direção, a Conve nção nº 163 da OIT ampara os referidos trabalhadores no que tange ao seu bem-estar nos mares, dentro das embarcações, e nos portos, momento em que os navios não estão em alto-mar (em águas territoriais brasileiras ou não). Primeiramente, o artigo $1^{\circ}$, I, a), define trabalhadores marítimos ou "marinheiros" como sendo "todas as pessoas empregadas, com qualquer cargo, a bordo de um navio dedicado a navegação marítima, de propriedade pública ou privada, que não seja um navio de guerra”. A definição é de suma importância, pois enquadra os trabalhadores que neste ramo laboram e como é, demasiadamente ampla, abrange os trabalhadores brasileiros de navios cruzeiro (navios de passageiros, de lazer). A alínea b) do mesmo artigo define serviços meios e serviços de bem-estar como sendo o bem-estar, em sentido lato, dos marítimos nos navios e nos portos, o acesso a meios culturais, recreativos, e à informação. ${ }^{15}$

$\mathrm{O}$ artigo $2^{\circ}$, I, demonstra a imperatividade da proteção a estes empregados, dizendo: "To do membro para o qual esteja em vigor esta Conve nção compromete-se a zelar para que sejam providenciados os meios e serviços de bem-estar adequados aos trabalhadores marítimos, tanto nos portos como à bordo de navios".

Não obstante as demonstrações garantistas anteriormente citadas, o $\operatorname{artigo~} 3^{\circ}$, I, da Convenção 163 completa o intuito protecionista da norma internacional, dizendo:

"Todo membro se compromete a cuidar para que sejam providenciados meios e serviços de bem-estar nos portos apropriados do país para todos os "marinheiros", sem distinção de nacionalidade, raça, cor, sexo, religião, opinião pública, ou origem social, e independentemente do Estado em que estiver registrado o navio a bordo do qual estejam empregados".

A clareza é de fácil percepção, contudo, a obscuridade no cumprimento destas

\footnotetext{
14 Ibid. p. 167.

15 Ibid. p. 421.
} 
normas que pertencem ao nosso ordenamento, pelos empregadores dos marítimos, prevalece. $^{16}$

Estas são algumas das Convenções da OIT de grande prestígio, relevância. No entanto, não são suficientes para sustentar tais trabalhadores perante as empresas empregadoras que tanto infringem as normas jurídicas internas e externas. É por esta razão que a atenção a este seleto grupo de empregados deve ser maior, pois que sofrem muito com o ferir de seus direitos.

Entretanto, há ainda aquelas Convenções que não foram ratificadas, e que portanto ainda não integram o ordenamento jurídico pátrio. Os doutos entendem que tais Tratados tem importante função, não sendo o fato de não possuírem caráter normativo um empecilho jurídico. A melhor forma de tratar as normas advindas destas é admitindo-as como diretriz/influência interpretativa e teleológica, o que em outros termos significa dizer que de vem ser tidas como doutrina.

A doutrina não tem a mesma finalidade da norma legal ou da jurisprudência, podendo até se basear nestas, porém visa a construção de um "ideário jurídico" apto a auxiliar os operadores do direito a desbravar os "mares da Ciência do Direito" ainda não descobertos. A communis opinio doctorum, para Paulo Nader, compõe-se de estudo e teorias desenvolvidos pelos juristas, com o objetivo de sistematizar e interpretar as normas vigentes e de conceber novos institutos jurídicos (...). ${ }^{17} \mathrm{~A}$ elaboração das Convenções na Assembléia Geral da OIT (Conferência Internacional do Trabalho) pelos Estados-membros, seus representantes, representantes dos trabalhadores e dos empregadores, reflete a criação de doutrina, pois que cria, sistematiza, e critica o mundo jurídico ao seu redor e no caso, as condições e relações de trabalho "lato sensu".

O que se quer aqui demonstrar é a grandeza jurídica encontrada em Convenções ainda não ratificadas. Tais Convenções tidas como doutrina, a qual é desenvolvida no plano teórico, oferecem subsídios valiosos ao legislador na elaboração dos

\footnotetext{
16 Ibid. p. 421.

${ }^{17}$ NADER, Pau lo. Introdução ao Estudo do Direito. 30ª ed. Rio de Janeiro: Forense, 2008. p. 181.
} 
documentos legislativos, ao intérprete operador do direito e àqueles para os quais a norma é destinada, pois estas influenciam os costumes internacionais e internos (o que é fundamental para os trabalhadores marítimos, porquanto o trato discriminatório é muito presente), e o processo de formação da norma jurídica que regulará as relações jurídicas entre os membros das sociedades espalhadas pelo mundo. Logo, não há outra conclusão a se chegar, a não ser a de que o argumento de autoridade, $a b$ auctoritate, deve ser considerado decisivo para o "trato jurídico" no que tange aos trabalhadores denominados marítimos, pois se assim o for, estes obterão uma tutela ainda maior e mais efetiva, capaz de ilidir o desamparo normativo. ${ }^{18}$

Desta forma, deve-se frisar a importância da entrada em vigor no plano internacional, em 20 de agosto de 2013, da Convenção 186 da OIT, sobre o Trabalho Maritimo, 2006 (MLC) ${ }^{19}$ adotada na $94^{\text {a }}$ sessão marítima da Conferencia Internacional do Trabalho e até agora ratificada por mais de 50 países ${ }^{20}$. E esta Convenção que moderniza e consolida um conjunto de Convenções da OIT sobre marítimos, busca primordialmente assegurar o direito de todos estes a um emprego digno e condições de trabalho decentes. A Convenção 186 - MLC está em tramitação no Congresso Nacional, e sua ratificação não de ve tardar.

A Convencão MLC 2006, como passou a ser conhecida, é dividida em Artigos, Regras e Código. Os dois primeiros versam sobre os direitos e princípios fundamentais, bem como as obrigações dos membros que ratificaram a Convenção. $\mathrm{O}$ Código versa sobre o modo de aplicação das normas.

O primeiro aspecto importante e que deve ser le vantado se encontra no artigo $2^{\circ}$, I, f), que é a definição de trabalhador marítimo, que passa a ser "qualquer pessoa empregada ou contratada ou que trabalha, a qualquer título, a bordo de navio ao qual se aplique a presente convenção", o que acaba por englobar os marítimos brasileiros

\footnotetext{
18 Ibid. p. 185.

19 O texto pode ser consultado em:

http://www.oitbrasil.org.br/content/convenção-sobre-trabalho-mar\% C3\%ADtimo. Ultimo acesso: 09.11.2013.

${ }^{20}$ para a listagem atualizada, consultar a base de dados da OIT, NORMLEX:

http://www.ilo.org/dyn/normlex/en/f?p=NORMLEXPUB:1:0::NO:::. Ultimo acesso: 09.11.2013.
} 
que laboram em navios cruzeiro. Assim, é possível o enquadramento e a representação sindical, de modo que as negociações coletivas e o direito à gre ve com a de vida participação sindical tornam-se viabilizados.

Deve-se mencionar ainda os direitos e princípios fundamentais insculpidos no artigo $3^{\circ}$ da mesma, quais sejam: princípio da liberdade de associação e o reconhecimento efetivo do direito de negociação coletiva; da eliminação de toda e qualquer forma de trabalho forçado ou obrigatório; da abolição efetiva do trabalho infantil; e da eliminação da discriminação em matéria de emprego e de profissão. Tutela-se, pois, o integrante da classe por todos os possíveis lados de deturpação da relação de trabalho.

O artigo $4^{\circ}$, em seu incisos I e III, explicita tal vez o direito de maior importância em todo Tratado, sendo este o direito a um local de trabalho seguro em que as normas de segurança sejam respeitadas, e à condições dignas de trabalho e de vida a bordo dos navios. Este "tom" garantista perfectibiliza a proteção à di gnidade da pessoa humana que em nosso ordenamento jurídico encontra-se na CRFB $/ 88$, artigo $1^{\circ}$, III, de modo que o trabalho não degrade as mínimas condições de vida e labor.

Com intuito de concluir a explanação sobre a importância da Convenção a ser seguida, insta ressaltar algumas garantias acolhidas pela mesma: a idade mínima para trabalhar a bordo de um navio como sendo de 16 anos, não podendo marítimos menores de 18 anos exercerem seus ofícios no período noturno (Regra 1.1 e Norma A1.1); previsão das condições de trabalho, de forma bem definida e clara, no respectivo contrato, de cumprimento obrigatório, e de acordo com as normas da presente Convenção (Regra 2.1); garantia de salário recebido regularmente e integralmente como forma de contraprestação laborativa (Regra 2.2); regulamentação prévia da duração do trabalho e do descanso, fixando um número máximo de horas a serem trabalhadas e um número mínimo de horas de descanso (Regra 2.3); garantia do direito à férias remuneradas por tempo adequado (Regra 2.4); possibilidade de repatriamento, ou seja, de regresso para casa, sem custos e nas condições especificados pelo código que compõe a Convenção, vide Norma A2.5, como quando 
o contrato de trabal ho cessar por iniciativa do marítimo, por justa caus a deste, quando o prazo estiver findo, entre outras hipóteses (Regra 2.5); assegurar alojamento e lazer descentes a bordo (Regra 3.1); proteção da saúde da classe garantindo-lhes acesso rápido a cuidados médicos a bordo ou em terra (Regra 4.1); possibilitar ambiente de trabalho dos marítimos a bordo dos navios de modo a contribuir para a saúde e segurança no trabalho, etc.

É desta maneira humanitária e digna que a doutrina insculpida neste tratado multilateral procura mostrar a este setor obreiro, que existe sim solução para os problemas enfrentados perante os empregadores e os demais Estados soberanos. O fiel seguimento da mesma proporcionará a limitação, ou até mesmo, a supressão do fenômeno da precarização do trabalho nesta seara, de maneira a efetivar interesses de todo e qualquer trabalhador marítimo, seja ele brasileiro ou não. 


\section{2o Capítulo - Contrato internacional de Trabalho e Lei aplicável.}

\subsection{O conflito de lei no espaço.}

Passamos a tratar, neste capítulo, de uma, questão de suma importância que envolve a proteção legal dos trabalhadores marítimos brasileiros que prestam seus serviços nos navios cruzeiro possuidores de bandeira diversa da de seu país de origem, em águas jurisdicionais brasileiras e/ou internacionais: a definição da lei aplicável ao contrato de trabalho do trabalhador em navios de cruzeiro de bandeira estrangeira Trata-se, assim, de tema que envolve o Direito do Trabalho, mas principalmente, o Direito Internacional Privado e suas diretrizes normativas, e que merece o foco que ora se passa a dar.

A priori, verifica-se que quando um trabalhador brasileiro firma contrato com empresas multinacionais, como são as que atuam no ramo dos "navios de passageiros", este se enlaça em um vínculo empregatício, que se explicita pelos requisitos fático-jurídicos previstos nos artigos $2^{\circ}$ e $3^{\circ}$ da CLT, que são: a prestação de labor por pessoa física; com pessoalidade; não e ventual; e com subordinação jurídica. É o que se verifica na prática e que continua a se propagar.

A primeira pergunta que se de ve fazer, quando um nacional firma o contrato de trabalho no Brasil, junto à empresa marítima internacional, para prestar seu labor, é: está este trabal hador de vidamente resguardado por al guma legislação nacional? Se a resposta for sim, qual lei de ve servir de amparo em caso de desrespeito a seus direitos, a doméstica ou a referente à bandeira do navio para o qual presta seus serviços? Isto depende do critério de DIPr que se irá utilizar.

A situação estereotipada evidencia um conflito de leis no espaço alusivo à proteção jurídica deste trabalhador que decide se aventurar nos mares nacionais e/ou estrangeiros. Tal embate jurídico é abarcado pelo Direito Internacional Privado, que conforme seu vasto regramento, dá espaço para mais de uma solução, o que permite 
efetivar a tutela condizente aos brasileiros que imbuídos de coragem e de uma concepção deturpada do meio ambiente laboral, se prestam a tal ofício. Verifica-se, pois, que o conflito de leis se instaura entre a legislação pátria e a legislação estrangeira, sendo crucial a tomada da melhor solução, pois que se assim não o for, aqueles permanecerão no já citado "limbo jurídico." 


\subsection{Utilização do método conflitual - regra de conexão tradicional.}

Antes de versar sobre este critério de solução de contro vérsias referentes às leis dos Estados soberanos que coexistem no mundo atual, mister se faz definir o DIPr como ciência jurídica para que, com base em sua conceituação e justificação, se caracterize o método conflitual e sua regra de conexão tradicional.

"O Direito Internacional Privado é um direito sobre o direito, com regras sobre a aplicação de um determinado direito, regulamentando a vida social das pessoas implicadas na ordem internacional." ${ }^{21}$ Esta lição de Nádia de Araújo, é elucidativa, na medida em que chama a atenção para o fato de ser este ramo do direito uma ciência que busca solucionar problemas que envolvem ordenamentos jurídicos diversos, seja pela conclusão sobre qual lei aplicar, seja pela aplicação do princípio do juiz natural, para definir regras de cooperação jurídica internacional, etc. É, portanto, instrumento que deve ser manuseado para promover a justiça nas sociedades.

Cabe, pois, salientar que os sistemas jurídicos, de um modo geral, contêm regras que se aplicam a essas situações conectadas a mais de um mesmo sistema, que são chamadas de regras de conexão ou normas indiretas ${ }^{22}$. Tais regras são responsáveis por pôr fim aos conflitos de leis, resolvendo a controvérsia acerca de qual ordenamento jurídico aplicar, mas não a materialidade da questão. Este critério se consolidou no século XIX, e está passando por grandes mudanças em face da flexibilização da regra de conexão tradicional, dando assim espaço para regras de caráter material $^{23}$, alternativas, de aplicabilidade imediata, e princípios como o da proximidade (ou vínculos mais estreitos), concretizarem os direitos de forma mais eficaz.

Neste sentido, o referido método soluciona o conflito de leis no espaço mediante a utilização de uma norma indireta que, por sua vez, designa a lei aplicável

\footnotetext{
${ }^{21}$ ARAUJO, Nadia de. Curso de Direito Internacional Privado. $5^{\mathrm{a}}$ edição. Rio de Janeiro: Renovar, 2011. p. 39.

${ }^{22}$ Ibid. p. 40.

23 Ibid. p. 44.
} 
ao caso concreto. A norma material não é fornecida por este, mas unicamente o ordenamento jurídico ao qual a norma aplicável deverá ser requerida. Não quer este promover a justiça material, mas a uniformização, a estabilidade e a continuidade na aplicação de regras de conexão, e conseqüentemente das situações jurídicas. ${ }^{24}$ Todavia, deve-se ressalvar que a uniformização desta prática é capaz de promover, muitas das vezes, grandes injustiças no seio social, de modo a não resguardar os direitos mais fundamentais da pessoa humana.

Alguns fins perseguidos por este critério tradicional como a igualdade do tratamento das pessoas, e a harmonia das decisões sobre uma mesma relação jurídica, não são capazes de omitir problemas como a possibilidade de cada Estado aplicar internamente a sua regra de conexão própria, o que possibilita a situação ser resolvida de várias formas, além de algumas destas decisões não serem aceitas em outros entes soberanos, e da alta probabilidade de as partes interessadas poderem realizar um "forum shopping", ou seja, a escolha de um foro onde a lei aplicável é mais favorável às partes ,burlando-se o regramento formal. ${ }^{25}$

É importante afirmar, assim, que o referido critério de DIPr varia de país para país, o qual reflete a norma de conexão tradicional, sendo nos países regidos pela civil law o da lex loci celebrationis e os caracterizados pela common-law o da lex loci executionis, ou seja, o da lei do local da celebração da obrigação e o da lei do local da execução da mesma, respectivamente. O Brasil como sendo adepto da civil law, adota o primeiro critério que está insculpido no artigo $9^{\circ}$ da LIN. Estes critérios, há muito utilizados, perderam um pouco do seu espaço para a utilização de princípios como o da proximidade, muito utilizado nos EUAe que reflete a opção pela lei mais próxima às características da situação jurídica internacional de cunho privado. ${ }^{26}$

Importa notar, também, que os contratos internacionais são internacionais, pois possuem um elemento de estraneidade que os ligam a dois ordenamentos jurídicos distintos, de dois Estados soberanos e autônomos e não distoa desta acepção

\footnotetext{
24 Ibid. p. 45.

25 Ibid. p. 46.

26 Ibid. p. 383
} 
o contrato de trabalho internacional dos trabalhadores marítimos brasileiros que aqui firmam o pacto para prestarem serviços em navios de bandeira de outro ente internacional. Além do fato de a estes serem aplicáveis regras de conexão, podem também estar inclusas cláusulas como a de lei aplicável e de eleição de foro, as quais ilustram o princípio da autonomia da vontade, que é responsável por solucionar, muitas da vezes, o conflito de leis e de jurisdição. Tais tópicos serão abordados mais a frente. $^{27}$

Há uma observação que muito enriquece o entendimento sobre este ponto do trabalho, sendo esta o fato de as regras de conflito variarem entre os entes internacionais. Dessa forma, buscou-se a uniformização destas normas bilaterais mediante a criação de regras internacionais uniformes (ocorrendo o mesmo com as regras materiais que também foram uniformizadas, e de que é exemplo a Convenção da UNCITRAL sobre Compra e Venda internacional), as quais trouxeram mais segurança jurídica e reduziram as possibilidades de forum shopping. ${ }^{28}$

Assim se firma o método conflitual exposto. As raízes da escola estatutária italiana, com fulcro em Bartolo, embasam os países regidos pela civil law, da mesma forma que a teoria do conflito de leis de Savigny é supedâneo jurídico para os países ancorados na commom-law, dadas as regras de conexão acima expostas. ${ }^{29}$ No entanto, não se pode deixar de enxergar o crescimento da utilização do princípio da autonomia da vontade, que não encontrou respaldo al gum na legislação brasileira, de modo que a utilização de cláusulas referentes a este princípio, como a de lei aplicável e de eleição de foro, tornam-se o meio apto a coadunar as modificações contratuais ao princípio supra. Permanece, contudo, até ulterior alteração legal e jurisprudencial, a regra geral do artigo $9^{\circ}$, caput, da LIN, embora o Brasil tenha assinado a Convenção Interamericana sobre o Direito Aplicável aos Contratos Internacionais, sem a ratificação da mesma. ${ }^{30}$

\footnotetext{
27 Ibid. p. 384

28 Ibid. p. 386.

29 Ibid. p. 387.

30 Ibid. p. 388.
} 
Percebe-se que nos últimos anos este método tem sido muito criticado por sua indiferença para com a realidade. ${ }^{31} \mathrm{O}$ que está a acontecer é uma verdadeira flexibilização em escala mundial deste, principalmente, pelos países europeus que passaram a admitir um pluralismo de métodos, e pelos Estados Unidos da América que atacaram-no frontalmente, de modo a se pautar, apenas na ponderação dos resultados advindos da aplicação das leis, preconizando o primado da "lei do foro". 32

Desta forma, quer-se modificar este pensamento de modo a adequar o método de solução de conflito de leis no espaço aos novos escopos do DIPRI, não sendo a segurança jurídica justificativa suficiente para embasar a fiel aplicação do mesmo. O critério defendido por muitos doutrinadores conservadores de ve ceder espaço para a prevalência de valores jurídicos superiores, quais sejam os direitos humanos fundamentais da pessoa humana, estando os direitos sociais incluídos neste amplo gênero, de maneira que, o direito à condições dignas de trabalho e ao amparo justrabalhista restem efetivados na prática, caso haja colisão com as normas bilaterais supracitadas.

É neste sentido que este trabalho se pauta. Quer-se mitigar o método conflitual tradicional do Direito Internacional Privado para realizar assim, os princípios e ideais mais básicos de justiça, de modo a resguardar esta categoria de trabalhadores, os de navio cruzeiro, incluídos neste conceito todos aqueles que prestam labor na embarc ação, operando-a ou não. Por fim, mister se faz ressaltar que esta mitigação de ve se dar tanto nos casos em que a regra de conexão apontar para o ordenamento jurídico brasileiro ou para o de outro Estado, de maneira que a aplicação da legislação mais favorável ao marítimo fique resguardada. As caus as de justificação desta proposta são: o princípio Protetor do Direito do Trabalho, o artigo $3^{\circ}$, II, da L. 7.064/82 (a qual assegura a aplicação da legislação brasileira à relação jurídica em que o empregado contratado ou transferido, presta serviços fora do território nacional), e o cancelamento da súmula 207 do TST, que previa regra de conexão

\footnotetext{
31 Ibid. p. 47.

32 Ibid. p. 49.
} 
específica para o ramo juslaboral. 


\subsection{O princípio da autonomia da vontade e a cláusula de lei aplicável.}

É sabido por toda a doutrina deste ramo do Direito, que o princípio da autonomia da vontade utilizado na determinação, do direito aplicável à situação jurídica que contém um elemento de estraneidade, é elemento que pode entrar em conflito com o referido critério tradicional. Antes de adentrar nas relevantes considerações relativas a este princípio de Direito Internacional Pri vado, necessária se faz a descrição da situação jurídica complexa que envolve estes trabalhadores: os contratos internacionais de trabalho.

Os trabalhadores marítimos a que tanto se alude, inserem-se nos navios cruzeiro mediante o firmamento do contrato de trabalho em solo brasileiro ou mediante promessas de ratificação do referido contrato quando já estão em alto-mar ou no porto de outro país, quando a embarcação atraca. No caso destes trabalhadores, conforme já afirmado no tópico anterior, o contrato caracteriza-se como sendo internacional, pois que possui um elemento de estraneidade capaz de ilustrá-lo dessa forma, qual seja, o fato de a prestação de serviços se dar em navio de bandeira de outro Estado, que muitas vezes não é o Estado que representa a empresa contratante. Trata-se de um "cenário desarranjado" que é o meio pelo qual o abuso do poder diretivo infringe os direitos sociais dos trabalhadores.

O princípio da autonomia da vontade nos contratos tem suas raízes em Charles Dumoulin, jurista francês do século XVI, que defendia a possibilidade de as partes escolherem a lei aplicável aos contratos internacionais e aos regimes patrimoniais ${ }^{33}$, e se desenvolve com base na perda da importância do local da celebração do contrato, dada a facilidade de circulação de informação e dos contratantes. Assim, pode-se negociar uma contratação de forma "ausente", o que não costuma ocorrer com a classe de trabalhadores que ora se versa. Por fim, resta dizer que o princípio tem ampla aceitação nos países da commom-law, além de refletir a nova tendência

\footnotetext{
33 Ibid. p. 391.
} 
jurisprudencial. $^{34}$

No Brasil o princípio foi acolhido por Clóvis Bevilaqua na antiga redação do artigo 13, caput, da LIN que dizia: "Regulará, salvo estipulação em contrário, quanto à substância e aos efeitos das obrigações, a lei do lugar onde forem contraídas." A expressão "sal vo estipulação em contrário" para este era autorizadora da utilização do princípio pela vertente da lei aplicável ao contrato. Entretanto, com a supressão da expressão, muitos juristas expuseram o entendimento no sentido de inadmitir a auto nomia da vontade nos contratos internacionais, e embora muitos sejam a favor, o princípio é proibido. ${ }^{35}$ Portanto, só será possível uma aplicação segura da referida norma, e da cláusula de lei aplicável consequentemente, se a LIN for modificada, pois se não o for, permanecer-se-á na indefinição.

Cabe neste momento a feitura de uma pequena consideração. A principiologia da autonomia da vontade pode ou não permear o contrato internacional de trabalho que envolve os trabalhadores marítimos. Esta reduzida explicação sobre a norma supracitada visa atender a didática do trabalho, ou seja, mostrar a tendência negocial, doutrinária, e jurisprudencial no sentido da aceitação daquela, sem o necessário aprofundamento que tal temática demanda. Independentemente disto, mesmo a intenção dos contratantes tenha sido de adotar o princípio da autonomia da vontade nos contratos internacionais de trabalho, interpreta-se em prol da sistemática aqui vers ada: em prol da legislação mais benéfica ao trabalhador. ${ }^{36}$

\footnotetext{
34 Ibid. p. 392.

35 Ibid. p. 394. p. 396. p.397.

36 Importa salientar que há o projeto de lei de $n^{\circ} 281$ do Senado Federal, que teve forte influência da professora Cláudia Lima Marques, e que visa, conjuntamente, a modificação de algu mas disposições gerais do Código de Defesa do Consumidor, L. 8.078/90, e a alteração da LIN, Decreto-Lei n ${ }^{\circ} 4.657 / 42$, que por sua vez, propiciará mudança substancial quanto ao entendimento sobre o princípio da autonomia da vontade e a cláusu la de lei aplicável. O novo artigo $9^{\circ}$ terá a seguinte redação: "O contrato internacional entre profissionais, empresários e comerciantes rege-se pela lei escolhida pelas partes, sendo que o acordo das partes sobre esta escolha deve ser expresso." Este dispositivo, por si só, resolve a dubiedade existente quando da aplicação do referido princípio. Todavia, o inciso VII do $\S 6^{\circ}$ do mes mo artigo esclarece: "Este artigo não se aplica às seguintes contratos e obrigações:(...) contratos de transporte, de seguro ou de trabalho.” Tal ressalva legal exp lic ita o que ora se versa com outras palavras, qual seja o fato de não ser cabível o princípio da autonomia da vontade e a cláusula de lei aplicável aos contratos de trabalho.
} 


\subsection{O princípio Protetor do Direito do Trabalho.}

Conforme já exposto antes, quer-se afastar a aplicação direta e automática do Decreto-Lei 4.657/42, antiga LICC, Lei de Introdução ao Código Civil, atual LIN, Lei de Introdução Às Normas do Direito Brasileiro, sem que seja feita, pre viamente, uma análise com base no princípio Protetor do Direito do Trabalho, no artigo $3^{\circ}$, II, da L. 7.064/82, e no cancelamento da súmula 207 do TST, que são "sustentáculos jurídicos" para que se possa optar pela lei mais benéfica aplicável ao caso concreto. Não se quer aqui impe dir ou "travar" a utilização da LIN, mas apenas fazer com que o seu uso se dê quando for mais favorável ao prestador de serviços marítimos. É com fulcro neste espectro que se passa agora a descrever uma das causas de justificação da interpretação dada.

É sabido de todos que a relação empregatícia é marcada pela existência de uma parte que é superior econômico, social e juridicamente (entendendo-se com relação a este último a capacidade de ter um patrocínio, de constituir advogado), que é o empregador, e de uma parte que caracteriza-se por estar, na maior das vezes, em sentido diametralmente oposto àquela, que é a hipossuficiente, o empregado. Portanto, a norma especial, comum ao ramo justrabalhista da grande maioria dos Estados Nacionais, visa expor uma ampla teia de proteção ao obreiro, que nesta relação jurídica é parte hipossuficiente. Esta é a teleologia do princípio: proteção social, econômica e jurídica. ${ }^{37}$

A normatividade extraída do princípio supra justifica, histórica e cientificamente, o Direito do Trabalho como ramo autônomo e especializado do Direito, na me dida em que evidencia o escopo tutelar que este tem para com a relação jurídica de cunho privado que é caracterizada por uma categoria fundamental, a relação de emprego. Verifica-se que este é um princípio cardeal que adentra em todos os outros princípios do ramo justrabalhista e que influi no regramento jurídico laboral de modo a garantir, efeti va e concretamente, a proteção do empregado. Na esteira do

37 DELGADO, Maurício Godinho. Curso de Direito do Trabalho. $9^{\mathrm{a}}$ ed. São Paulo: LTr, 2010. p. 183. 
jurista uruguaio Américo Plá Rodrigues, este se desdobra em três outras diretrizes normativas, quais sejam, o princípio do in dubio pro operario, o da interpretação e aplicação da norma mais favorável ao trabalhador, e o da condição mais benéfica de labor. $^{38}$

A idéia basilar propagada por este núcleo central que se ramifica no Direito do Trabalho e no Direito Processual do Trabalho é a de retificar juridicamente a reconhecida desigualdade socioeconômica e de poder entre os sujeitos da relação de emprego $^{39}$, de maneira a permitir a exteriorização dos direitos e de veres de ambas as partes para assim, fazer jus aos ideais de justiça social insculpidos na Carta da República. É o que se visa para os trabalhadores marítimos brasileiros sobre os quais se disserta, pois que não são ape nas partes hipossuficientes na relação jurídica firmada com a empresa mediante o contrato de trabalho, mas partes desprotegidas e desassistidas pela le gislação vigorante, tanto nacional, na qual não há normatização específica, quanto estrangeira, o que deve ser entendido com ressalvas, pois a Convenção dos Trabalhadores Marítimos de 2006, que topograficamente comporá o ordenamento jurídico pátrio como lei ordinária federal, está em vias de aprovação.

\footnotetext{
${ }^{38}$ Ibid. p. 183
}

39 Ibid. p. 184. 


\subsection{O cancelamento da súmula 207 do TST e a L. 7.064/82.}

A súmula 207 do TST é de grande valia para o estudo aqui feito, pois que explicitava uma regra de conexão que regia as relações privadas de cunho internacional como as referentes ao marítimos brasileiros que laboram em navios cruzeiro de bandeira estrangeira, onde vigora, teoricamente e prima facie, a lei do Estado representado pela bandeira, segundo a perspectiva deste Estado, que felizmente, não é a que se está a defender. O critério tradicional de resolução de conflitos entre leis no espaço abrangido pela súmula, era o da lex loci executionis, que assenta que a lei aplicável a um possível conflito de interesses de índole trabalhistaé a lei do local da execução dos serviços, e no caso ora analisado, a do Estado ilustrado pela bandeira alçada no navio.

Com o cancelamento do enunciado jurisprudencial de $n^{\circ} 207$ do Tribunal Superior do Trabalho a interpretação que passou a ser dada foi no sentido de priorizar o artigo $9^{\circ}$, caput, da LIN, o que acabou por beneficiar parte destes obreiros, em especial, aqueles que firmaram o contrato de trabalho no Brasil, pois que preleciona o referido artigo que a lei aplicável à relação jurídica com vistas ao autodesfazimento, é a do local da celebração da obrigação, ou seja, do contrato de trabalho que é o instrumento normati vo que atribui direitos e obrigações a ambas as partes. Assim, se o pacto laboral perfectibilizou-se no Brasil, pelas leis deste será regido, assim como eventual litígio.

A hipótese citada conforta um pouco os operadores do direito, pois que o ordenamento jurídico que recairá sobre a situação jurídica comple xa será o brasileiro e estes trabalhadores terão, ainda que minimamente, seus direitos resguardados, segundo as regras materiais de direito individual e coletivo do trabalho. Todavia, deve-se atentar para o fato de que não se quer assegurar a incidência da lei brasileira, mas sim a da lei mais favorável ao trabalhador, independentemente do que dispuser a regra de conexão.

O entrave está no que diz respeitos aos brasileiros que ratificam seu contrato no 
navio ou no porto de outro Estado Nacional onde o navio atraca. Estes por celebrarem o negócio obreiro em território que não o brasileiro terão, pela regra de conexão doméstica, e quiçá também pela lei do país onde o pacto foi celebrado, a relação jurídica juslaboral orquestrada pela lei do Estado representado pela bandeira do navio. Eé nesta situação que os empregados ficam mais vulneráveis, de maneira que passam a sofrer todo tipo de abuso e excesso do poder diretivo do empregador, tal como o frequente assédio moral Este ponto será aprofundado em tópico posterior.

Por sua vez, a lei 7.064/82 é de suma importância para o estudo que se realiza, pois, junto ao princípio Protetor do Direito do Trabalho, confere legitimidade à argumentação jurídica desenvolvi da até então. Conhecida também como "Lei Mendes Júnior", porque inicialmente se aplicava apenas a empresas prestadoras de serviços de engenharia, foi objeto de ampliação de seu escopo pela Lei 11.962 de 2009. Atualmente, a Lei 7.064 possui o escopo de amparar os trabalhadores que são contratados ou transferidos para o exterior, em que se enquadram os marítimos brasileiros que prestam serviços nos referidos navios. O inciso II do $\operatorname{artigo} 3^{\circ}$ da mesma lei dispõe:

"A empresa responsável pelo contrato de trabalho do empregado transferido assegurar-lhe-á, independente da observância da legis lação do local de serviços: a aplicação da legis lação brasileira de proteção ao trabalho, naquilo que não for incompatível com o disposto nesta Lei, quando mais favorável do que a legis lação territorial, no conjunto de normas e em relação a cada matéria."

Percebe-se, pois, que o dispositivo anteriormente citado tem o condão de traçar uma linha de proteção, indo ao encontro do princípio Protetor, de modo a tutelar a relação jurídica do trabalhador que é contratado ou transferido para no exterior laborar. Ademais, trata-se de regra que se adapta ao artigo 469, caput, da Consolidação das Leis do Trabalho, e que portanto, está em harmonia com o regramento trabalhista pátrio. Desta forma, de ve estar bem clara a idéia de que a todo brasileiro transferido, e aqui se incluem os obreiros de navios cruzeiro, se aplica a legislação trabalhista doméstica de proteção a este, se esta for mais benéfica que a lex loci executionis, e não for de encontro às leis brasileiras. Porém, quer-se ir além. O objetivo é readaptar o que se insculpiu no inciso II do artigo $3^{\circ}$ da L. 7.064/82, de 
modo que, junto à norma protecionista especial, permita-se a aplicação da lei mais favorável seja ela brasileira ou estrangeira. Esta é a exegese amplamente protetiva, de feição vanguardista, que se quer incutir no pensamento dos operadores do Direito. 


\subsection{Conflito de jurisdição. Competência concorrente da Justiça do} Trabalho.

Temática importante que mostra vínculo indissociável com a discussão acerca da lei aplicável ao caso dos brasileiros marítimos que firmam contrato de trabalho no Brasil, é a da jurisdição. De nada adiantaria uma conclusão coerente sobre o conflito de leis se não fosse solucionado, conjuntamente, a dubiedade relativa a este instituto de Direito Processual. Ajurisdição, ou melhor, a iuris dicto, é explicável pelo o intuito de "dizer o direito", garantindo ao detentor de uma posição jurídica de vantagem, a proteção e a efetivação de sua pretensão que se encontra resistida. Assim, indispensável se faz a feitura de algumas considerações sobre esta, visto que complementa o raciocínio desenvolvido em cima da possível lei aplicável à situação jurídica complexa.

Pode-se iniciar a ventilação deste tema com a afirmação de que a jurisdição é dividida em parcelas pelo Estado, para que a solução dos eventuais litígios se dê de maneira mais especializada e célere. Importa, pois, dizer que a jurisdição internacional revela-se pelas regras de competência, que no ordenamento jurídico pátrio encontram-se reguladas no Código de Processo Civil, nos artigos 88, referente à competência concorrente, 89, relativo à competência exclusi va, e 90, sobre ausência de litispendência internacional, os quais referem-se, por óbvio, à competência internacional, ou seja, a capacidade de se reconhecer a extensão da jurisdição brasileira parajulgar de mandas privadas de cunho internacional.

Interessa para a abordagem aqui feita, o artigo 88 e incisos, do $\mathrm{CPC}$, pois que vers a sobre a competência concorrente da justiça brasileira, e aqui, especificamente, a do trabalho, dada a aplicação subsidiária do Código Processo Civil, nos termos do artigo 769 da CLT c/c artigo 114, I, da CRFB para o julgamento de conflitos que envolvem este trabalhadores marítimos. Ressalta-se que a doutrina especializada na área de DIPr e o Superior Tribunal de Justiça firmaram o entendimento no sentido de não ser necessária a cumulação dos incisos I, II e III, do artigo 88 do CPC para 
estabelecer a competência da justiça brasileira, bastando apenas a ocorrência de um dos pressupostos assentados nos referidos incisos para que aquela seja reconhecida. ${ }^{40}$ Sendo assim, passa-se a análise dos incisos do referido artigo.

O inciso I do artigo 88 estabelece que é competente a autoridade judiciária brasileira quando o réu, qualquer que seja a sua nacionalidade, estiver domiciliado no Brasil. Cabe notar que este primeiro inciso deve ser conjugado com o parágrafo único do mesmo artigo, que considera domiciliada no Brasil a pessoa jurídica estrangeira que aqui tiver agência, filial, ou sucursal. Desta forma, verifica-se que a hipótese do trabalhador brasileiro marítimo que firma contrato internacional de trabalho no Brasil ou no exterior junto a empresa internacional ou brasileira, para laborar em águas jurisdicionais brasileiras ou internacionais, a qual possui domicílio (compreendidas as filiais agências e sucursais do empregador estrangeiro) no Brasil, e que ingressa com reclamação trabalhista neste, encontra respaldo legal que atribui competência à justiça do trabalho para jul gar tais c asos. Tal hipótese engloba o labor em águas jurisdicionais pátrias e internacionais, visto que sempre haverá filial ou sucursal da empresa contratante no Brasil.

No que tange ao inciso II do mesmo artigo, verifica-se que é também competente a justiça brasileira, quando no Brasil tiver de ser cumprida a obrigação. Este pressuposto retrata a situação em que o marítimo nacional é contratado para “operar na embarcação” em águas territoriais brasileiras, e que portanto, confere parcela de jurisdição à justiça especializada do trabalho para conhecer e julgar eventuais litígios ocorridos entre a empresa e o obreiro.

Por fim, o inciso III dispõe que será concorrentemente competente o judiciário brasileiro, quando a ação se originar de fato ocorrido ou de ato praticado no Brasil. Enxerga-se, no vamente, a competência da justiça trabalhista para a prestação da tutela jurisdicional, visto que comporta a hipótese de ato ou fato antijurídico praticado pelo empregador, contra o empregado, em navio que percorre águas jurisdicionais brasileiras.

40 ARAUJO, Nadia de. Op cit., p. 231. 
Deve-se, pois, ter em mente que, independentemente de a competência ser concorrente, o reconhecimento desta à justiça do trabalho é crucial para o real amparo jurídico desta classe de trabalhadores, visto que, conforme prelecionado no artigo $6^{\circ}$, caput, c/c o artigo 193, caput, da Carta Magna, este órgão jurisdicional têm como objetivo primordial a garantia da justiça e ordem social, sendo a diretriz constitucional citada o fim através do qual se realizam os meios promotores de justiça. A Justiça do trabalho é um meio de promoção da justiça, e portanto, torna-se imperioso o reconhecimento da competência deste órgão especializado para dirimir tais lides.

A determinação da competência para julgamento deve se dar em duas etapas: na primeira o poder judiciário analisa se possui competência internacional, à luz dos artigos 88, 89, e 90 do CPC. Posteriormente, este passa a definir a sua competência interna de maneira a verificar se faz jus às regras processuais internas de definição de competência. $^{41}$

Ainda se faz pertinente a dissertação sobre dois últimos pontos que também são de extrema relevância para a temática que se está a expor, quais sejam, o entendimento de que o rol do artigo 88 do CPC não é taxativo, mas meramente exemplificativo, conforme dito anteriormente, e a aplicação do forum non conveniens. No que diz respeito a primeira consideração, adere-se a melhor interpretação do dispositivo, com fulcro em Marcelo de Nardi e José Carlos Barbosa Moreira, que afirmam não ser restritivo o rol do artigo 88 do CPC, de modo que a existência de "elemento de fixação de competência", que é o fato de saber se a eficácia do contrato se dará no estrangeiro ou no Brasil, sobre o qual De Nardi versa, e a possibilidade do surgimento de casos em que seja absurdo e inviável a negação da tutela jurídica estatal, ante a ausência de base legal, justificam a hermenêutica que recai sobre o dispositivo, pois que possibilita-se assim, a aplicação de normas de competência interna à situações internacionais não respaldadas pelo referido artigo. ${ }^{42}$ Esta concepção também deve ser dada aos eventuais conflitos oriundos da relação

\footnotetext{
41 ARAUJO, Nadia de. Op cit., p. 233.

42 ARAUJO, Nadia de. Op cit., p. 237. p. 238. p. 241. p. 242.
} 
empregatícia que envolva os trabalhadores marítimos em geral.

Resta assim, a explanação acerca de instituto de muita valia para a common-law, o forum non conveniens, que implica o reconhecimento da inconveniência do julgamento pela justiça competente, dadas as facilidades de se obterem provas e de se efetuar o melhor julgamento em outra diversa daquela. É comum os juízes dos Estados Unidos da América, declinarem de sua competência para que outro pudesse exercer efetivamente a jurisdição. Isto ainda não é aceito no Estado brasileiro, mas é supedâneo jurídico que flexibiliza as regras processuais de competência internacional e proporciona uma melhor prestação da jurisdição aos jurisdicionados. 


\subsection{O princípio da autonomia da vontade e a cláusula de eleição de} foro.

Neste momento, e com a finalidade de encerrar de maneira coerente e coesa o capítulo, passa-se à explanação do princípio da autonomia da vontade e da cláusula de eleição de foro que em suma, proporciona a mesma conclusão referente ao debate travado no tocante à cláusula de lei aplicável. A utilização do princípio, e consequentemente, da cláusul a já citada, podem ou não estar presentes na prática que consolida os contratos de trabalho internacionais desta categoria profissional, o que faz da demonstração dada a seguir um requisito de coerência e coesão para com o trabalho, versando-se assim, dentro do enfoque do DIPr, sobre a relação da cláusula de eleição de foro e a competência internacional concorrente do judiciário brasileiro, aqui representado pela justiça do trabalho.

$\mathrm{Na}$ verdade, trata-se de um conflito, um embate, que existe entre a autonomia da vontade contr atual e a competência concorrente, porque, se admitido for o efeito da cláusul a de foro, eleito estará o foro escolhido (estrangeiro ou pátrio) que seráo único competente para processar e julgar a demanda, de modo que, se o eleito for algum foro internacional, o recurso à jurisdição brasileira embasada no artigo 88 do CPC restará comprometido, estando inviabilizada a análise do caso concreto pelo Poder Judiciário do Estado brasileiro. Entretanto, esta acepção é a mais moderna, a qual alguns doutrinadores, como o ex ministro do STF Carlos Alberto Menezes Direito, se filiam.

Cabe ressaltar que o STJ se manifestou, por diversas vezes, no sentido de considerar a regra relativa à competência internacional como sendo uma regra imperativa e que não pode ser derrogada, a priori, pela vontade das partes. Isto não obsta o fato de o posicionamento da Corte Superior não ser uno, fechado, havendo dissidências que se ligam a aceitação da cláusula, principalmente, quando não 
estiverem envolvidos interesses públicos. ${ }^{43}$

Há, portanto, filiações para ambos os lados, porém, se o negócio jurídico internacional for referente a trabalhadores que independentemente de serem marítimos, forem prestar seus serviços fora do território nacional, deve este ser submetido à justiça trabalhista brasileira, se verificados os requisitos legais pátrios, consolidando-se assim, o entendimento conservador do STJ (estando afastada a cláusula de eleição de foro), eis que estarão os direitos mais fundamentais da pessoa humana, assegurados, vide artigo 88 do CPC c/c artigo 769 da CLTc/c artigo 114, I da CRFB.

${ }^{43}$ ARAUJO, Nadia de. Op cit., p. 248. 


\section{3ํ Capítulo - Trabalhadores em navios cruzeiro.}

\subsection{Trabalhadores marítimos brasileiros e navios cruzeiro.}

Neste capítulo, de índole lógico-sistemática, far-se-á uma explanação conjuntural que permita o leitor a compreensão, por inteiro, da situação jurídico-social desta classe de trabalhadores.

Estes aventurados brasileiros que se iniciam nestas jornadas de trabalho em navios cruzeiro, como dito no decorrer do trabalho, não têm a segurança jurídica advinda do resguardo hermenêutico-jurídico dos direitos trabalhistas de qualquer nacional que exerça suas funções em qualquer ramo de trabalho. Ficam à margem da legislação laboral pátria e internacional, pois que o reconhecimento de "situações jurídicas de vantagem" pouco acontece pelos outros países. Cabe ao ordenamento jurídico brasileiro conceder e aplicar a legislação mais benéfica, atribuindo ao foro trabalhista brasileiro competência para exercer a jurisdição estatal, no melhor interesse destes, desde que atendidos os requisitos doutrinários e legais aqui expostos, visto que muito já sofrem com a incorreta denominação da categoria, a ausência de enquadramento sindical apropriado, vide artigo 577 da CLT, e a ausência de supedâneo jurídicos justificadores de uma proteção legal efetiva.

São seres humanos que muito influenciados pelo fenômeno da internacionalização do trabalho, o qual camufla as verdades sobre este setor obreiro, buscam a melhoria das condições de trabalho, e conseqüentemente de vida, sob uma ótica um tanto quanto deturpada da realidade nestas embarcações. Sugere-se até a mudança da expressão dada até agora de "trabalhadores de navios cruzeiro", para "trabalhadores de navios cruzeiro que laboram em condições análogas a de escravo". Diz-se isso com base no citado Termo de Ajuste de Conduta de $\mathrm{n}^{\circ} 408 / 2010$, firmado pelo Ministério Público do Trabalho, que proporciona mediante uma interpretação a contrario sensu, a conclusão acerca da existência destas condições. Os marítimos brasileiros, que prestavam serviços para a empresa MSC CRUZEIROS DO BRASIL 
LTDA, por exemplo, cumpriam a jornada de trabalho sem ter o descanso derivado dos intervalos inter e intra jornada, pagavam os exames admissionais que faziam para a própria empresa, sofriam assédios sexuais e morais, não tinham instalações sanitárias condignas, não tinham água potável disponibilizada, tendo que pagar pela mesma, dentre outras inadmissibilidades que lhes acometiam.

É de se admitir assim, que se está a tratar de uma categoria sui generis a qual merece um olhar minucioso dos operadores do direito que militam em tal área, pois apenas uma interpretação unívoca acerca da lei aplicável à situação jurídica complexa que circunda tais trabalhadores, aliada ao entendimento positivo no sentido de conferir competência à justiça laboral brasileira, pode, em suma, assegurar-lhes o verdadeiro amparo protetivo de sede constitucional. Neste sentido, busca-se a alçada destes obreiros a um patamar digno e legítimo, com base em pre visão legal específica (com a já citada Convenção 186 da OIT, sobre trabal hadores marítimos, a MLC 2006, que está em vias de aprovação), no efetivo enquadramento sindical da categoria profissional segundo os ditames do artigo 577 da CLT para representação no plano coletivo, e com a observância do exercício da jurisdição pela justiça especializada trabalhista.

Espera-se, pois, que o já citado "limbo jurídico" desapareça para proporcionar a realização concreta da justiça social no "alto-mar" enfrentado pelos bravos compatriotas. 


\subsection{Prestação laborativa em águas territoriais brasileiras e estrangeiras: lei aplicável e jurisidição.}

Retoma-se aqui o que foi anteriormente explicitado no $2^{\circ}$ Capítulo para que se faça uma análise que proporcione objetivar a teleologia contida neste trabalho. Falou-se no conflito de leis no espaço, no conflito de jurisdição, e nas repostas dadas pelo Direito Internacional Privado brasileiro acerca dos dois tópicos dissertados, no que tange, obviamente aos marítimos brasileiros que prestam serviços nas embarcações tantas vezes aqui mencionadas. $\mathrm{O}$ trabalho tido em justificar a aplicação da lei mais benéfica ao trabalhador em voga, seja el a brasileira, ou estrangeira, mesmo quando a LIN aponta para outro norte, é árdua, pois ainda percebe-se a influência que o conservadorismo jurídico exerce sobre a sociedade na qual habitamos. Quer-se mediante uma criação jurídica baseada na escola da exegese, que no caso se debruça sobre Princípio Protetor do Direito do Trabalho e no artigo $3^{\circ}$, II, da L. 7.064/82, assegurar uma interpretação, a qual é sucedida pela aplicação da legislação mais favorável, ao contrato internacional de trabalho deste ser político que corriqueiramente encontra-se em situação de penúria. Busca-se, assim, o mínimo ético, que é por sua vez, assegurado constitucionalmente, conforme artigo $6^{\circ}, 7^{\circ} \mathrm{e}$ incisos, $8^{\circ}, 9^{\circ}, 10,170,193$, entre outros.

Todavia, só é possível assegurar a incidência da "melhor lei" a este trabal hador se se reconhecer previamente a competência da Justiça do Trabalho para exercer uma das expressões do poder soberano do Estado, qual seja, a resposta jurídica estatal razoável e proporcional à realidade. A conclusão ora feita se dá com base no artigo 88 e incisos do CPC c/c artigo 769 da CLT c/c artigo 114, I da CRFB/88, que reconhece a competência internacional da justiça especializada brasileira. Deste modo, verifica-se que a peculiaridade aqui defendida visa resguardar no plano social, econômico e jurídico, os direitos de nacionais que labut am com um forte companheiro ao seu lado: o desprestígio.

O "destino jurídico" destes brasileiros pode sim ser o melhor, pois segundo 
Willian Jennings Bryan “destino não é uma questão de sorte, mas de escolha”, e pode-se escolher os meios mais aptos à garantia de uma tutela efetiva desta classe que tanto sofre quando labuta. 


\subsection{A atuação do Ministério Público do Trabalho.}

O Ministério Público do Trabalho é peça-chave para o deslinde dos conflitos aqui suscitados, visto que é, por excelência, órgão que, segundo o artigo 127, caput, da CRFB, tem o condão de primar pelos direitos coletivos, difusos, transindividuais, sociais e individuais indisponíveis, de qualquer pessoa natural. Atribuições outras possui o MPT, como membro do Ministério Público da União, conforme artigo 128, I, b), da CRFB, assim como o Ministério Público Estadual, o Ministério Público Federal, e o Ministério Público Militar, tais como a defesa da ordem jurídica e do regime democrático, que legitimam esta instituição essencial à função jurisdicional, e que nos pormenores aqui apresentados, representam os interesses sociais dos marítimos brasileiros que sonham com a justiça social em seu ramo de trabalho.

É, pois, instituição que compõe "o todo orgânico" e que confere harmonia ao complexo de relações jurídicas justrabalhistas formadoras daquele. Sem a atuação precípua do dominus litis, muito pouco se teria avançado na conquista e garantia de direitos sociais trabalhistas na República Federativa do Brasil, de que é exemplo o Termo de Ajuste de Conduta de $\mathrm{n}^{\circ}$ 408/2010, de abrangência nacional, firmado pelo MPT, por procuradores da Procuradoria Regional do Trabalho da $1^{\circ}$ Região, que foi o instrumento normati vo que primeiro regularizou com o vigor necessário, o labor da categoria marítima em águas jurisdicionais brasileiras, sendo passível de execução na justiça reconhecidamente competente, a justiça juslaboral, vide artigo $5^{\circ} \S 6^{\circ}$ da $\mathrm{L}$. $7.347 / 85$.

Importa salientar, que este órgão que atua junto à Justiça do Trabalho exerce funções institucionais previstas no artigo 129 , da CRFB, e $6^{\circ}$ e $7^{\circ}$ da $L C \mathrm{n}^{\circ} 75 / 93$, as quais são de muita valia para os membros desta classe sócio-laboral, sendo as principais: promover o inquérito civil público e a ação civil pública para a proteção dos interesses difusos e coletivos, além dos procedimentos preparatórios de inquérito, e a expe dição de notificações nos procedimentos administrati vos de sua competência, requisitando informações e documentos para instruí-los, vide incisos III e VI do artigo 
129 da CRFB, respectivamente. Os artigos $6^{\circ}$ e $7^{\circ}$ da $L C n^{\circ} 75 / 93$ têm o condão de explicitar a atividade investigatória do MPT, a qual se funda nos procedimentos administrativos supracitados, e que é de grande valia para os empregados marítimos brasileiros, porquanto proporciona-se a formação de TAC's ou até mesmo o oferecimento de ações ci vis públicas capazes de trazer a tutela jurisdicional do Estado para aqueles.

Em suma, o MPT, por meio de suas procuradorias, é, dado o seu dever constitucional, o grande defensor daqueles que laboram embarcados, pela via administrativa mediante procedimentos administrativos previstos na Resolução $n^{\circ}$ 69/2007 do Conselho Superior do Ministério Público do Trabalho, que cumprem as finalidades preventiva, reparatória, e repressiva aos ilícitos, que não são condição de procedibilidade para o ajuizamento das ações civis públicas, as quais por sua vez, asseguram os direitos sociais trabalhistas em juízo. Portanto, verifica-se que a "simbiose jurídico-administrativa" explicitada pela atuação do membro do MPT, seja ele procurador do trabalho, ou procurador regional do trabalho, é por ora, a única porta aberta para estes brasileiros, e que por isso, deve ser valorizada e enxergada como o meio capaz de trazer concretude ao princípio constitucional da dignidade da pessoa humana, segundo artigo $1^{\circ}$, III, da CRFB, nas relações empregatícias. 


\subsection{A concretização das cláusulas constitucionais - artigo $6^{\circ}$ e $7^{\circ}$, XXII e XXXI da CRFB.}

A busca pela aplicação inequívoca da lei mais favorável, conjugada com a admissão da justiça obreira como competente para prestar a tutela jurisdicional em face de lesões, ou ameaças de lesões a direitos, e com a atuação precisa do MPT, acaba por derradeiro, a concretizar cláusulas constitucionais assecuratórias que visam a perfectibilização do direito social ao/do trabal ho. Tais dispositivos são o $\operatorname{artigo} 6^{\circ}$, caput, da CRFB, que define o direito ao/do trabalho como um direito social, e que portanto, se inscre ve na ordem social prevista no artigo 193 da CRFB, e o os incisos XXII e XXXI do artigo $7^{\circ}$ da CRFB que dizem respectivamente, que são direitos de trabalhadores outros que não os urbanos e rurais, como os marítimos, que visem à melhoria da sua condição de vida, a redução dos riscos inerentes ao trabalho, por meio de normas de saúde, higiene, e segurança, além da proibição de qualquer discriminação no tocante a salário e critérios de admissão do trabal hador portador de deficiência.

Tais normas foram exaltadas, porque são as que possuem maior relevo quando se trata de trabalhadores marítimos, visto que os riscos advindos da relação de trabalho que se perfazem uma embarcação, são altos e noci vos à saúde daquele que lá labora, não havendo muitas das vezes higiene, saúde, e sequer segurança, que os permita exercer o seu ofício dentro de certos "padrões normais" de trabalho. Da mesma forma, as contínuas práticas discriminatórias permanecem presentes no dia a dia destes operários, principalmente no tocante aos seus salários, havendo formas de burla da legislação brasileira e internacional, pre vistas em Convenções da OIT, que amparam a contraprestação laborativa devida àqueles com base no princípio da isonomia.

Luta-se não pelo melhor dos mundos, mas pela garantia de uma vida digna. Este é o objetivo constitucional e o escopo deste trabalho. 


\subsection{Acesso à Justiça dos trabalhadores brasile iros em navios cruzeiro.}

Por fim, resta falar da garantia constitucional processual insculpida no artigo $5^{\circ}, \mathrm{XXXV}$, da CRFB, que assegura a todos o direito de acesso à justiça, quando preleciona: "a lei não excluirá da apreciação do poder judiciário lesão ou ameaça a direito". Torna-se imperioso alertar-se para o fato de que, conforme famoso douto ${ }^{44}$, não se quer garantir um mero acesso formal ao Poder Judiciário, mas à uma "ordem jurídica justa", a qual consiste na prestação da tutela jurisdicional, aos titulares de posições jurídicas de vantagem, de modo eficaz.

Neste momento, não se pode deixar de mencionar a doutrina perfilhada pelo ilustre processualista italiano Mauro Cappelletti, que criou as chamadas "três ondas do acesso à justiça", indispensáveis a melhor compreensão deste trabalho, quais sejam: a garantia da assistência judiciária gratuita, a proteção dos interesses metaindividuais, mediante instrumentos coletivos e difusos, e a efetiva proteção dos interesses dos jurisdicionados.

A primeira onda, consistente na proteção jurisdicional dos economicamente necessitados, ou hipossuficientes, foi plenamente incorporada pelo ordenamento jurídico brasileiro, tanto no plano legal, pela L. 1.060/50 que garante a gratuidade de justiça no que tange aos pagamentos das despesas processuais, quanto na ceara constitucional, me diante a combinação dos artigos $5^{\circ}$, LXXIV, e 134, da Lei Maior, que explicita um dever do Estado e um direito do nacional de ter a assistência jurídica integral e gratuita prestada pelo ente político, às pessoas que demonstrarem hipossuficiência de recursos. Percebe-se nesta segunda parte o realce constitucional dado à Defensoria Pública que é ele vada ao patamar de instituição essencial à função jurisdicional do Estado-Juiz. ${ }^{45}$

Prosseguindo-se à análise, verifica-se a necessidade de tutela que os interesses supraindividuais requerem. Nosso sistema jurídico abarca três, dentre outros,

\footnotetext{
${ }^{44}$ CÂMARA, Alexandre Freitas. Lições de Direito Processo Civil. $20^{\mathrm{a}}$ ed. Rio de Janeiro: 2010. Vol. I. p. 38. ${ }^{45}$ Ibid. p. 39
} 
mecanismos processuais capazes de concretizar tais interesses, que são a ação popular, intentada para repelir possíveis lesões ao meio ambiente, à moralidade administrativa, e ao patrimônio histórico, cultural e paisagístico, a ação civil pública que possui rol de legitimados apto a lutar por tais direitos, sendo instrumento de grande valia para os membros do MPT na luta pelos interesses das classes mais desprovidas, e o mandado de segurança coletivo, que apesar de também possuir rol específico de legitimados, visa o resguardo de direitos líquidos e certos de coletividades necessitadas. Conclui-se, pois, que restam bem amparados os direitos transindi viduais.

Por fim, resta falar da terceira onda integradora do princípio de Direito Processual explicitado, a qual se consubstancia na efetividade do exercício da tutela jurídico-estatal. Deste ponto, três vetores podem ser observados: a Reforma do Poder Judiciário, pela EC n 45/04, que proporcionou uma reestruturação e o resguardo do ambiente democrático, sendo exemplo disso a criação do Conselho Nacional de Justiça, a de "desformalização" dos procedimentos judiciais, esta sim, capaz de garantir a informalidade controlada necessária à celeridade processual, e a utilização de meios alternati vos de solução de contro vérsias, como a mediação, a conciliação e a arbitragem. ${ }^{46}$ Percebe-se que os três vetores acima descritos são plenamente aplicáveis na seara juslaboral, e principalmente, no que tange a classe de trabalhadores aqui versada.

Indaga-se: por que se escolheu o tema "acesso à justiça", ou "acesso à ordem jurídica justa”, para finalizar a exposição fundamentada sobre os conflitos de lei e de jurisdição concernentes aos trabalhadores marítimos brasileiros? A resposta é de fácil dedução. Simplesmente, porque assegurar a esta categoria profissional a melhor lei a ser aplicada, seja ela doméstica ou estrangeira, e a competência da justiça especializada trabalhista para o exercício do poder soberano do Estado de interpretar e julgar conforme os ditames legais, é admitir a materialização desta garantia constitucional processual que se afasta de seu aspecto formal, para se aproximar do

\footnotetext{
${ }^{46}$ Ibid. p. 43.p. 44.
} 
direito fundamental a ser corporificado na prática. Apenas uma interpretação jusgarantista é hábil a feitura de uma verdadeira re volução, que no caso ora versado, se exemplifica na situação jurídica complexa dos seafarers, que deve ser levada ao poder judiciário especializado. 


\section{CONCLUSÃO}

Não restam considerações acerca do tema, a não ser as de cunho conclusivo, as quais também já foram explicitadas ao longo do trabalho.

Buscou-se demostrar e justificar o que qualificamos de "limbo jurídico" no qual se encontram os trabalhadores brasileiros que são empregados por empresas estrangeiras para trabalhar em navios de cruzeiro. A incerteza sobre a lei aplicável ao contrato de trabalho, a dificuldade de levar as violações ao judiciário, e a ausência de um arcabouço normativo internacional vigente no Brasil deixam esses trabalhadores em condição de especial vulnerabilidade.

Desta forma, sendo aprovada a Convenção, não mais será necessário o esforço hermenêutico/doutrinário, feito neste trabalho, no que tange ao conflito de leis no espaço, para reservar não só a esta, mas a todas as outras categorias em situação similar, porém em especial nesta, a aplic ação da legislação mais favorável, visto que o Tratado incorporado dotado de força de lei ordinária federal, será a lei mais benéfica. Entretanto, no que diz respeito ao conflito de jurisdição, pre valecerá o entendimento aqui firmado, continuando a ser competente a Justiça Juslaboral, haja vista a adequação às normas processuais e constitucionais, artigo 88, I, II, III, do CPC e artigo 114, I, da CRFB/88, e à teleologia assentada no trato da questão processual, eis que, ontologicamente, se está a falar da fração do Poder Judiciário que melhor resolverá os possíveis litígios advindos da relação jurídica privada de cunho internacional.

Neste momento, em linhas objetivas e bem específicas, finaliza-se com o pensamento tantas vezes aqui descrito: os conflitos de leis no espaço e de jurisdição não são óbices à preservação e ao amparo sócio-jurídico do trabalhador marítimo brasileiro em navios de cruzeiro estrangeiros; devem ser solucionados com base na interpretação que se faz em conjunto do Princípio Protetor do Direito do Trabalho brasileiro, do artigo $3^{\circ}$, II, da L. 7.064/82, do cancelamento do enunciado jurisprudencial de $n^{\circ} 207$ do Tribunal Superior do Trabalho, na ausência da 
Convenção de 2006 da OIT sobre trabalhadores Marítimos, que caso seja aprovada, instaurará uma normatização capaz de assegurar os ditames constitucionais insculpidos no postulado da dignidade da pessoa humana, que por sua vez, se desdobra e alcança a dignidade no trabalho.

Espera-se, por fim, ter-se clareado, ainda que minimamente, a intenção exposta, pois que, se os operadores do Direito assim entenderem, interpretarem e aplicarem em sua prática, estarão os marítimos brasileiros e estrangeiros enveludados pelos sentimentos de justiça social e de isonomia material. 


\section{BIBLIOGRAFIA}

\section{. SÍTIOS VISITADOS:}

- MATTOS, Vivian Rodrigues. O trabalho na era da globalização. Disponível em <http:// jus.com.br/revista/texto/4845/o-trabalho-na-era-da-globalizacao〉. Acesso em 23 de março de 2013.

- GODOY, Dagoberto Lima. Globalização e Trabalho: por quê e o que flexibilizar. <http://www.white.oit.org.pe/dial2002/documentos/globalizacao_trabalho_flexibiliz ar.pdf >. Acesso em 23 de março de 2013.

- FASSARELA, Lúcio. Globalização do Trabalho. <http://blog.ufes.br/luciofassarella/2013/04/05/internacionalizac ao-do-trabalho>. Acesso em 02 de abril de 2013.

\section{. OBRAS CONSULTADAS:}

- SUSSEKIND, Arnaldo. Convenções da OIT. 2a ed.. São Paulo: LTr, 1.998. 623 p.

- ARAUJO, Nadia de. Curso de Direito Internacional Privado. $5^{\text {a }}$ ed.. Rio de Janeiro: Renovar, 2011.660 p. 
- NADER, Paulo. Introdução ao Estudo do Direito. $30^{\mathrm{a}}$ ed.. Rio de Janeiro: Forense, $2.008 .438 \mathrm{p}$.

- DELGADO, Maurício Godinho. Curso de Direito do Trabalho. $9^{a}$ ed.. São Paulo: LTr, 2010. 1.373 p.

- CÂMARA, Alexandre Freitas. Lições de Direito Processual Civil. $20^{\mathrm{a}}$ ed.. Rio de Janeiro: 2010.566 p.

- SILVA, De Plácido E. Vocabulário Jurídico. 28ª ed.. Rio de Janeiro: 2009. 1.492 p. 